\title{
Fold structure and underground drainage pattern in the alpine karst system Hochifen-Gottesacker
}

\author{
NiCO GOLDSCHEIDER
}

Key words: Hydrogeology, karst aquifer, fold structure, tracer test, Alps, Helvetic nappes, Schrattenkalk, Gottesacker

\begin{abstract}
This paper summarises seven years of hydrogeological research in the alpine karst system Hochifen-Gottesacker (Germany/Austria). Geologically, the site belongs to the Helvetic nappes and consists of Cretaceous sedimentary rocks. The Schrattenkalk limestone forms a relatively thin karst aquifer above or between thick marl aquicludes, forcing groundwater to flow parallel to the strata. The limestone is intensively cut by faults and fractures favouring karstification. The fault offsets are relatively small, so that their influence on the large-scale groundwater flow paths is limited. The site is thus ideal to study the influence of fold structures on the drainage pattern. Multi-tracer tests with a total of 16 injections demonstrated that troughs of plunging synclines form the main underground flow paths, while crests of anticlines act as local groundwater divides in the higher karst zones where the base of the aquifer is above the level of the surrounding valleys. In an adjacent valley that receives inflow from several synclines, tracer tests confirmed a major underground drainage system running across the folds. An axial culmination in the area is part of the continental water divide Rhine-Danube; an axial depression acts as a zone of confluence.
\end{abstract}

\section{ZUSAMMENFASSUNG}

Dieser Artikel fasst die Ergebnisse von sieben Jahren hydrogeologischer Forschung im alpinen Karstsystem Hochifen-Gottesacker zusammen (Deutschland/Österreich). Das Gebiet gehört zu den Helvetischen Decken und besteht aus Sedimentgesteinen der Kreide. Der Schrattenkalk bildet einen geringmächtigen Karstaquifer oberhalb bzw. zwischen mächtigen Mergelformationen. Der unterirdische Abfluss erfolgt überwiegend schichtparallel. Der Kalkstein ist stark geklüftet und von Störungen durchzogen, was die Verkarstung begünstigt. Der Versatz der Störungen und somit auch ihr Einfluss auf die grossräumigen Fliesswege ist aber recht gering. Das Gebiet ist deshalb ideal, um den Einfluss der Faltenstrukturen auf das Entwässerungsmuster zu studieren. Durch Markierungsversuche mit insgesamt 16 Eingaben konnte gezeigt werden, dass die Troglinien der abtauchenden Synklinalen unterirdische Abflussbahnen bilden, während die Scheitellinien der Antiklinalen als lokale Wasserscheiden wirken, zumindest in den Hochlagen, wo sich die Aquiferbasis oberhalb des Talniveaus befindet (seichter Karst). In einem angrenzenden Tal, das die unterirdischen Zuflüsse aus mehreren Synklinalen sammelt, konnte ein Entwässerungssystem quer zum Faltenbau belegt werden. Eine Achsenkulmination im Gebiet ist Teil der kontinentalen Wasserscheide RheinDonau; eine Achsendepression bildet eine hydrologische Sammelstruktur.

\section{Introduction}

About one third of the Alps are formed of carbonate rocks, most of which are karstified (Fig. 1). Karst aquifers hold important groundwater resources that are important for the drinking water supplies of the alpine countries, e.g. $50 \%$ in Austria. Many cities in the alpine region, e.g. Vienna and Grenoble, depend on such resources (Trimmel 1998). At the same time, karst aquifers are vulnerable to contamination. Contaminants may easily enter the subsurface and rapidly spread in the conduit system without effective attenuation. Therefore, these resources need special protection (Drew \& Hötzl 1999, Zwahlen 2004).

Karst aquifer systems are present in almost all major tectonic units of the Alps, mainly in the South Alpine, Aus- troalpine and Helvetic nappes. Their underground drainage pattern is controlled by various climatic, hydrologic and geologic factors, and landscape history.

Many karst systems in the South Alpine and Austroalpine zones consist of Triassic carbonate sequences with up to $4 \mathrm{~km}$ total thickness. Their drainage pattern is mainly controlled by the hydrologic base-level conditions, the faults and, if present, the dip of the underlying aquiclude, while folds are less important (Zötl 1961, Hötzl 1998). The Dachstein (Bauer 1989), the Tennengebirge (Toussaint 1971, Audra 1994) and the Schneebergalpen (Maurin \& Zötl 1959) in Austria are well known examples for this type of deeply karstified plateaux.

Most karst areas in the Helvetic zone of the Swiss Alps consist of a sequence of Jurassic and Cretaceous karst aquifers

Centre of Hydrogeology (CHYN), University of Neuchâtel, 11 Rue Emile-Argand, CH-2000 Neuchâtel, Switzerland. E-mail: nico.goldscheider@unine.ch 


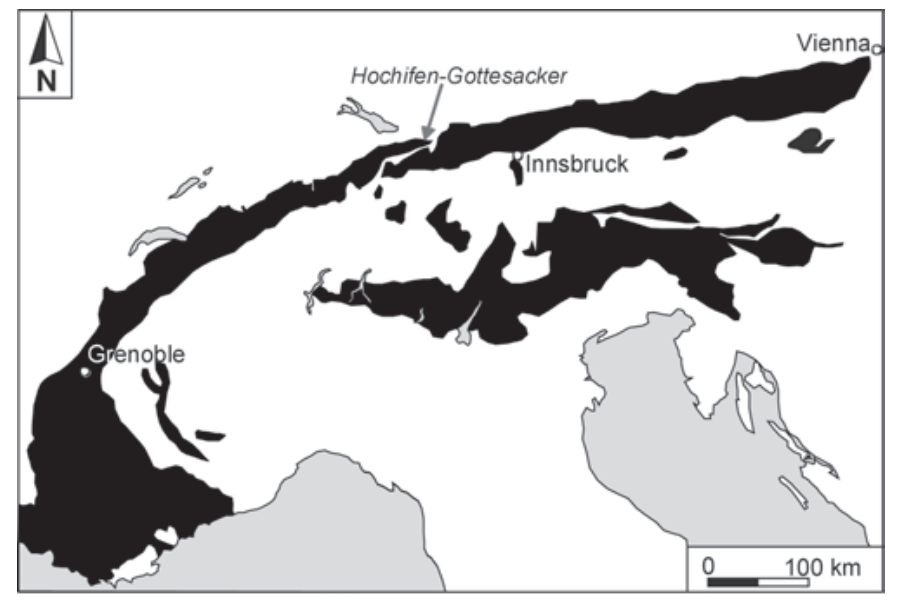

Fig. 1. Karst areas in the Alps and three important cities that are supplied by drinking water from alpine karst aquifers. The Hochifen-Gottesacker area is situated at the eastern end of the Helvetic zone, near the contact to the Austroalpine zone. Karst areas outside the Alps are not shown.

and marl aquicludes. The Quinten limestone (OxfordianTithonian, up to $400 \mathrm{~m}$ thick), and the Schrattenkalk limestone (Barremian-Aptian, up to $150 \mathrm{~m}$ ) are the most important karst rocks. The complex lithostratigraphy and the presence of folds and all types of faults make it difficult to study the pure influence of the folds on the drainage pattern. Faults may form preferential flow paths, cause hydraulic short-circuits between different aquifers, or form hydraulic limits (Herold et al. 2000). Thrusts may multiply the stratigraphic sequence and create multi-aquifer systems. The Hölloch-Muotatal and the SäntisChurfirsten areas (Bögli \& Harum 1981, Jeannin 2001, Rieg 1994) are examples for that type of karst system. The Siebenhengste-Hohgant region also belongs to the Helvetic zone. As there are no important folds in this area, the drainage is largely controlled by the dip of the strata, the faults, and the base level conditions (Häuselmann et al. 1999, 2003). There are also karst areas in the Penninic nappes, e.g. the Sulzfluh Plateau (Wildberger 1996). Recent research proved karst development in conglomerates of the Molasse zone (Göppert et al. 2002).

The karst system presented in this paper is part of the Helvetic zone. In contrast to the above mentioned areas, both stratigraphy and the fault pattern are relatively simple, while there are a variety of fold structures: six anticlines and five synclines, which rise to an axial culmination and plunge to an axial depression. There are open and tight folds, with an uprightsymmetric or asymmetric geometry. Along the crests of some anticlines, the karst aquifer is eroded, while overlying marls are locally preserved along the synclines. The site is ideal to study the influence of fold structures upon the underground drainage pattern.

Geomorphological and speleological research on this karst landscape started at the beginning of the $20^{\text {th }}$ century and is still in progress (e.g. Eckert 1902, Wagner 1950, Cramer 1959, Schmidt-Thomé 1960, Spöcker 1961, Scholz 1995, Rosendahl

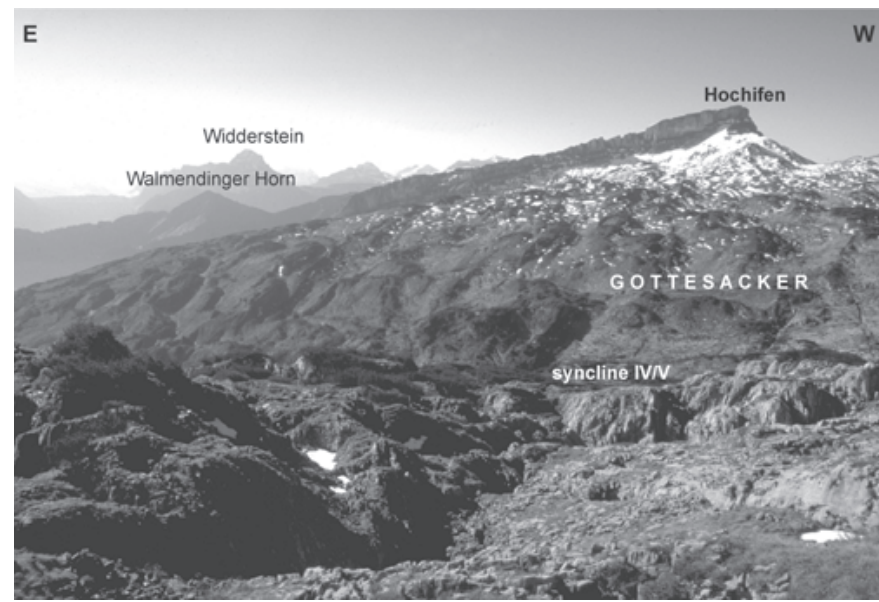

Fig. 2. The test site from the north. The karstified Schrattenkalk limestone forms the entire land surface of the Gottesacker and the summit of Mt. Hochifen (Helvetic nappes). Syncline IV/V is the main fold structure in the area. The Walmendinger Horn consists of Flysch (Ultrahelvetic and Penninic nappes). The Widderstein belongs to the Austroalpine nappes.

2000). Apart from some early local tracer tests in caves and observations at selected springs, there was no systematic hydrogeological research. This may be due to the fact that most springs in the area do not appear as suitable drinking water sources due to high contents of bacteria and organic carbon. Furthermore, the location at a political border makes it difficult to organise large tracer tests. Recent hydrogeological research in the test site started with the diploma work of the author and continued within the framework of his $\mathrm{PhD}$ thesis and three diploma theses (Goldscheider 1997, 2002, Tomsu 1998, Sinreich 1998, Huth 1998). Selected aspects were already published (Goldscheider \& Hötzl 1999, Goldscheider et al. 1999, Goldscheider 2000, Goldscheider et al. 2001, Sinreich et al. 2002). This paper summarises the results of the hydrogeological research in this alpine karst system and focuses on the relation between fold structures and drainage pattern.

\section{Geographic and geological overview}

\subsection{Location, climate and karst landforms}

The Hochifen-Gottesacker area is situated in the Northern Alps at the border between Germany (Bavaria, Allgäu Alps) and Austria (Vorarlberg, Bregenzerwald Mountains). Mt. Hochifen $(2230 \mathrm{~m})$ is the highest summit; the Gottesacker is a large karrenfeld covering a surface of about $10 \mathrm{~km}^{2}$ (Fig. 2). The Schwarzwasser and Breitach valleys in the $\mathrm{S}$ and $\mathrm{E}$, the Subersach valley in the $\mathrm{W}$ and two high valleys in the $\mathrm{N}$ form the natural boundaries. The total size of the investigated area including the surrounding valleys is about $72 \mathrm{~km}^{2}$.

The elevated parts of the Gottesacker $(>1600 \mathrm{~m})$ consist of bare limestone with abundant karren features, vertical shafts and karst corridors. In the lower areas, the limestone is covered with shallow soil and overgrown with forest. There are 24 


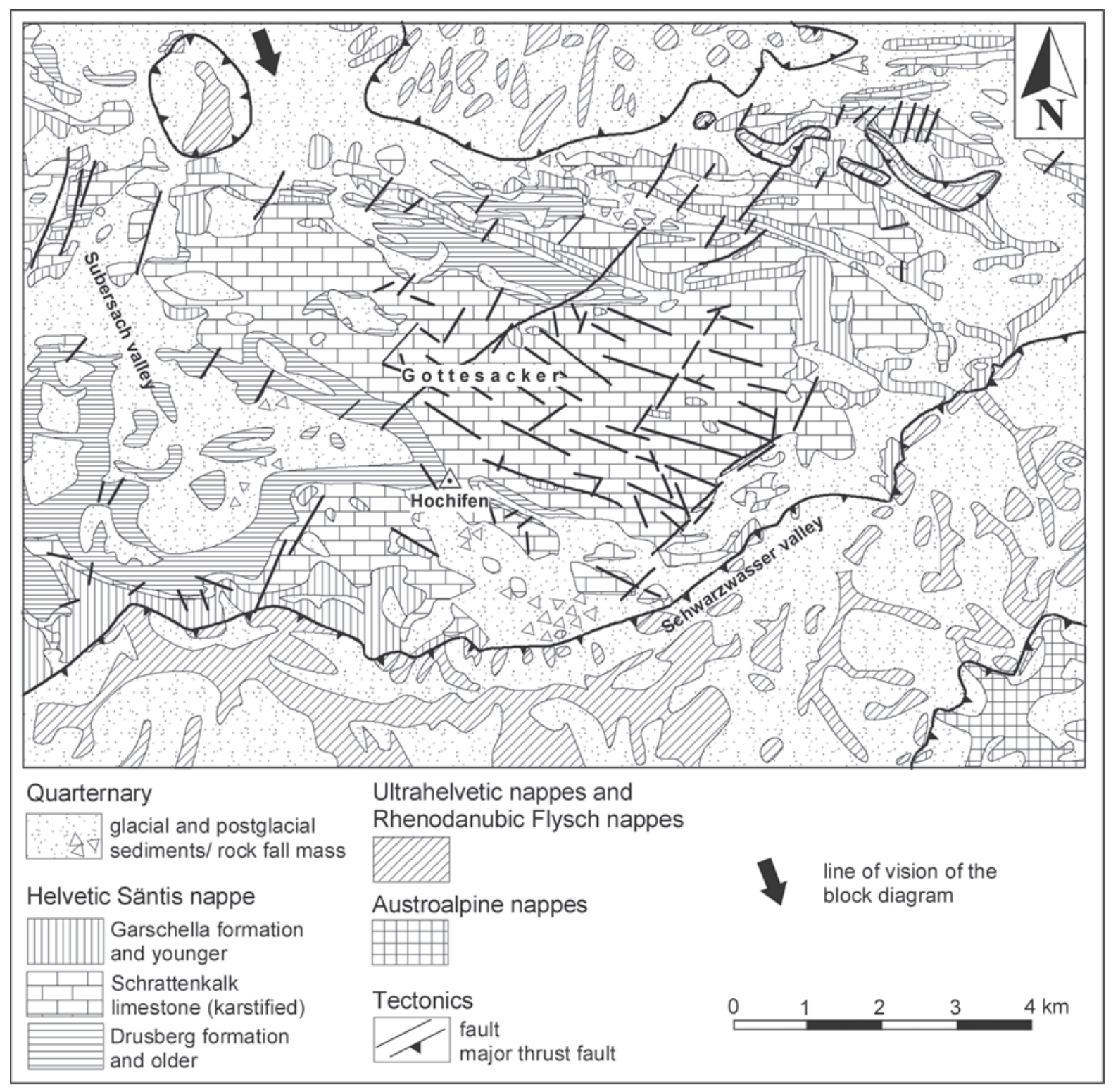

Fig. 3. Generalised geological map of the test site (modified after Zacher 1985). Schrattenkalk limestone outcrops on the entire land surface of the Gottesacker. Younger formations are preserved along the troughs of the synclines. Older formations are exposed in the cores of eroded anticlines and in the southern Subersach valley. The Schwarzwasser valley follows the contact between the Helvetic zone and the Flysch.

caves in the area; the largest one is the $9343 \mathrm{~m}$ long Hölloch. The morphology and genesis of the exokarst and caves were described in detail by Eckert 1902, Wagner 1950, Cramer 1959, Schmidt-Thomé 1960, Goldscheider et al. 2000, Fumy et al. 2000, and Rosendahl 2000.

There is no weather station in the test site. The nearest station in the Breitach valley $(1140 \mathrm{~m})$ gives a mean annual precipitation of $1836 \mathrm{~mm}$ and an air temperature of $5.7^{\circ} \mathrm{C}$. In the elevated parts of the test site, precipitation is certainly higher and a large proportion falls as snow. Since the vertical temperature gradient in the Alps is $0.6{ }^{\circ} \mathrm{C} / 100 \mathrm{~m}$, a mean tem- perature of $0{ }^{\circ} \mathrm{C}$ is expected at $2100 \mathrm{~m}$; evapotranspiration is thus low. Due to scarce vegetation and intense karstification, a large proportion of the precipitation contributes to recharge.

\subsection{Stratigraphy}

Four main geological units form the Bregenzerwald Mountains and Allgäu Alps: the Helvetic, Penninic and Austroalpine nappes, and the Molasse zone. The Helvetic zone is mainly represented by the Säntis nappe, which forms a large tectonic 


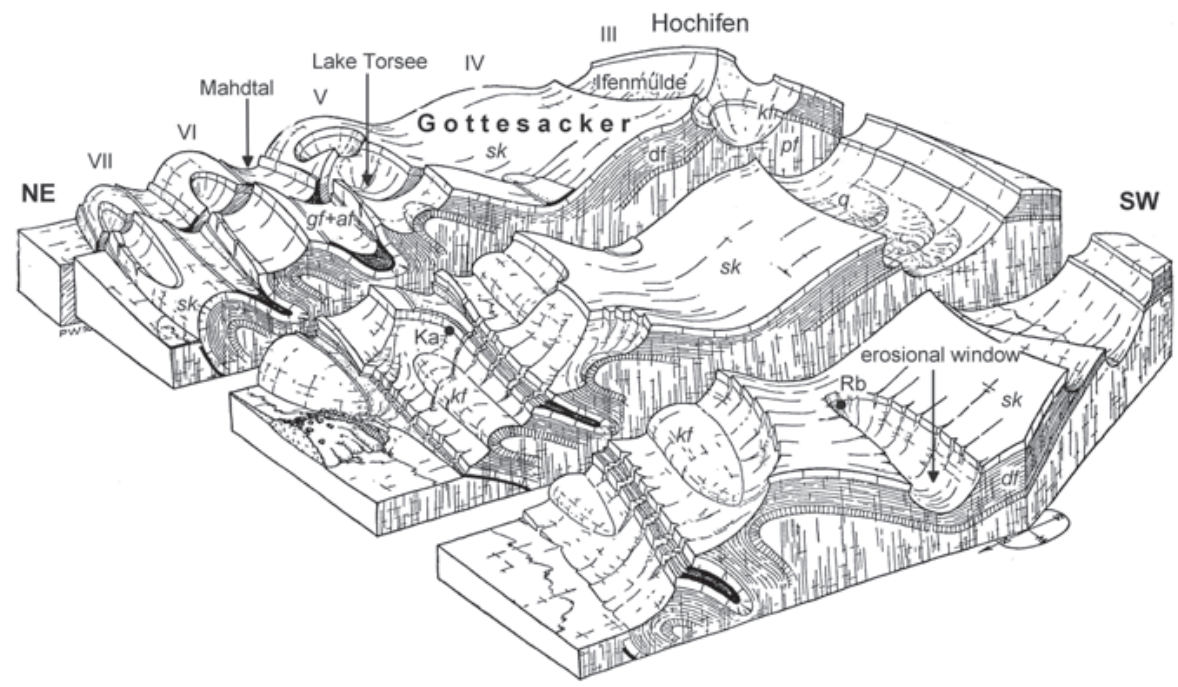

Fig. 4. Block diagram of the Hochifen-Gottesacker area, view from NW. Lithostratigraphy (formations): Palfris (pf), Kieselkalk (kf), Drusberg (df), Schrattenkalk (sk), Garschella (gf), and Amden (af), Quaternary deposits (q). Geological structures: Anticlines in roman numerals. An important NE-trending left-lateral strike-slip fault cuts through anticlines V-VII. Hydrology: Lake Torsee, Kessleralp spring $(K a)$, Rubach $(R b)$ spring (Wagner 1950, supplemented). half window (Wyssling 1986). To the N, S and E, the Säntis nappe plunges under the surrounding Ultrahelvetic and Penninic Flysch nappes. The test site is located at the eastern section of this half window and consists of Cretaceous sedimentary rocks. The Schwarzwasser valley follows the contact between the Säntis nappe and the Flysch, which forms the mountain range SE of the valley (Figs. 2 and 3).

Most formations within the Helvetic zone are characterised by lateral facies changes (Scholz 1995, Schwerd 1996). The following description of the lithostratigraphy applies to the test site only. The oldest rocks are marls of the Palfris formation (Berriasian-Valanginian). The Kieselkalk formation (Hauterivian) is up to $60 \mathrm{~m}$ thick and consists of impure silicic limestone containing quartz sand and chert nodules. The Drusberg formation (Barremian-Aptian) is composed of a well-bedded, monotonous alternation of marl and marly limestone with a total thickness of up to $250 \mathrm{~m}$ (Bollinger 1988). These formations mainly outcrop in the western part of the area, in the cores of eroded anticlines.

The Schrattenkalk limestone (Barremian-Aptian) is the most prominent rock in the area. It forms the surface of the Gottesacker, the summit of Hochifen, and the steep gorges in the valleys. The rock is very pure $\left(97 \%\right.$ of $\left.\mathrm{CaCO}_{3}\right)$ and mainly consists of fossil detritus (Scholz 1995). Its thickness ranges from $75 \mathrm{~m}$ in the $\mathrm{N}$ to $125 \mathrm{~m}$ in the $\mathrm{S}$ (Zacher 1973). At the northern margin of the Gottesacker, the boundary between the Drusberg marl and the Schrattenkalk limestone is sharp and clear. At its southern margin, the thickness and purity of the limestone banks within the Drusberg formation increases towards the top of the formation with a gradual transition to Schrattenkalk facies. Further to the S, there is more than 100 $\mathrm{m}$ alternation of marl and limestone banks of several metres thickness each.

The Garschella formation (Aptian-Cenomanian) shows important lateral changes in facies and thickness (Föllmi 1986, Föllmi \& Ouwehand 1987). In the test site, it consists of glau- conitic sandstone, 0 to $8 \mathrm{~m}$ thick. In the uppermost section of the Schwarzwasser valley, there are paleokarst features in the Schrattenkalk limestone that are filled with sandstone (Sinreich 1998). The Seewerkalk formation (Turonian-Santonian) is missing in most parts of the area. The Amden formation (Santonian-Campanian) consists of $250 \mathrm{~m}$ of monotonous marl with intensive cleavage. In the test site, these formations are preserved in the cores of synclines and along the contact between the Helvetic and Flysch nappes (Fig. 3).

The stratigraphy of the Ultrahelvetic and Penninic Flysch is not relevant for this paper. In the study area, the Flysch consists of a variety of clayey, marly and sandy sedimentary rocks.

The main valleys are mostly covered with moraines and alluvial sediments. An important rockfall mass of about 10 million $\mathrm{m}^{3}$ precipitated from the S slope of Mt. Hochifen after deglaciation and came to rest in the upper Schwarzwasser valley. As the river is dammed at this obstacle, an alluvial plain formed upstream of the rockfall mass.

\subsection{Folds}

Structurally, the area is characterised by folds. As the sedimentary sequence comprises competent limestone and incompetent marl formations, tectonic shortening resulted in flexural-shear folds (Eisbacher 1996). The brittle limestones were fractured, while penetrative shear deformation predominates in the marls. Wagner (1950) describes 11 fold trains in the eastern section of the Säntis nappe and numbered the anticlines from $\mathrm{S}$ to $\mathrm{N}$ in roman numerals; the synclines are numbered by combining the numerals of the bordering anticlines. Six anticlines (II-VII) and five synclines (II/III-VI/VII) are situated in the area (Fig. 4). Some folds are continuous; others end at faults or coalesce with adjacent folds.

Fold axes largely trend W-E, wavelengths range between 1 and $2 \mathrm{~km}$, amplitudes reach $800 \mathrm{~m}$. As the Schrattenkalk 
limestone forms large parts of the land surface, the topography often coincides with the folds: anticlines form ridges, while synclines form valleys. However, there are also examples of relief inversion: in places where the limestone is removed along the crest of an anticline, the underlying marl formations are eroded so that deep valleys form, surrounded by steep limestone rock faces. The most important example for relief inversion is the western section of anticline III, which was deeply eroded, so that the entire stratigraphic sequence from Palfris marl to Schrattenkalk limestone is exposed (Fig. 4).

The topographic culmination of the area coincides with a regional axial culmination. From this culmination, the fold axes plunge in a western direction towards an axial depression in the Subersach valley, and in an ESE direction towards the Schwarzwasser valley, where they disappear below the Flysch. The area is not only an axial culmination but also an anticlinorium, which reaches its highest altitude in anticline III.

The degree of tectonic shortening increases from $\mathrm{E}$ to $\mathrm{W}$ : folds are open in the eastern and tight in the western part of the area. Gently folded limestone is thus preserved along the Schwarzwasser valley, while the Subersach valley cuts through the limestone in the tight anticlines, exposing the underlying marl. Fold geometry also changes from $\mathrm{N}$ to $\mathrm{S}$ : in the southern and central part, folds are open and more or less symmetric (anticlines II-IV). In the northern part, folds are tight and north-verging, with gentle backlimbs and upright to overturned forelimbs (V-VII). Along the crests of these tight anticlines, the limestone is often eroded so that the underlying marl is exposed, mainly in the central part of the folds, near their culmination. The overlying sandstone and marl are preserved along synclines V/VI and VI/VII. Large parts of the Gottesacker are formed by syncline IV/V (Fig. 2). In the central and eastern section of this syncline, the karst limestone forms almost the entire surface. In the western section, it is locally eroded so that the underlying marl outcrops in an erosional window (Figs. 3 and 4).

\subsection{Faults}

A network of faults, most often with small displacements, cuts the area (Fig. 3). Within the limestone, the fault surfaces are sub-vertical and often form fault scarps at the land surface. Within the under- and overlying marl, deformation is rather penetrative. There are two important types of faults: NW tending right-lateral strike-slip faults with a shortening component, and NE tending left-lateral strike-slip faults with an extensional component. Three large NE faults cross the area. The first follows the Subersach valley (Oberhauser 1951). The second follows the culmination line and cuts through anticlines $\mathrm{V}$ to VII with a displacement of $120 \mathrm{~m}$ (Fig. 4). The third runs parallel to the Schwarzwasser valley. The fold pattern is different on either side of these faults, indicating that faulting started before the end of folding. Due to the extensional component, open fissures formed and were later filled with calcite veins. There are no thrust faults in the area.

\section{Hydrogeology}

\subsection{Hydrostratigraphy}

Compared to other karst systems within the Helvetic zone, the hydrostratigraphy of the Hochifen-Gottesacker area is relatively simple: a roughly $100 \mathrm{~m}$ thick karst aquifer that is underlain and, locally, overlain by marl aquicludes.

The Kieselkalk limestone outcrops only locally and plays no important role in the regional hydrogeology. The Drusberg formation mainly consists of marl and forms a major aquiclude. The limestone banks within the transition zone of the Drusberg and Schrattenkalk facies may form thin karst aquifers.

The Schrattenkalk limestone is the most important karst rock in the Helvetic zone. Due to its mechanical strength and chemico-mineralogical purity, it is extremely karstifiable. Fracturing and high precipitations also favour karstification. Areas formed of this limestone drain underground. In the zone of shallow karst, groundwater flow takes place near the contact of marl and limestone, e.g. the Hölloch cave stream in syncline V/VI.

The Amden marl is nearly impermeable and forms a thick aquiclude on top of the karst aquifer, together with the Garschella sandstone. The Amden marl always drains by surface runoff and often forms the substrate of wetlands. In other parts of the Helvetic zone, however, the Garschella formation consists of karstifiable rocks and forms a hydrogeological unity with the Schrattenkalk limestone (Bögli \& Harum 1981).

The sedimentary rocks within the Flysch zone are mainly characterised by low to moderate permeability and often drain by surface runoff. The composition of the Quaternary deposits is highly variable. Permeable glacial sediments cover large parts of the Schwarzwasser valley but hold no important groundwater resources as they are drained by the underlying karst aquifer. Small porous aquifers are present in moraine and rockfall material on top of marl, e.g. in the eastern section of anticline III, where the limestone was locally eroded ('Ifenmulde', Fig. 4). In the Subersach valley, a porous aquifer ('Iferwies') developed in glacial-alluvial sediments overlying the Helvetic formations in the core of syncline IV/V. The rockfall mass in the upper section of the Schwarzwasser valley is the most interesting Quaternary aquifer in the area and was studied in great detail by Sinreich et al. (2002).

\subsection{Hydrology}

The test site is located at the continental water divide between the catchments of the Rhine (North Sea) and Danube (Black Sea). The eastern part of the area is tributary to the Danube, via the rivers Schwarzwasser, Breitach and Iller. The western part is tributary to the Rhine, via Subersach and Bregenzerach. Fig. 5 shows the important springs and surface waters in the area. Tab. 1 summarises their characteristics. The given discharge values are estimations on the basis of occasional flowmeasurements using the salt-dilution method. 


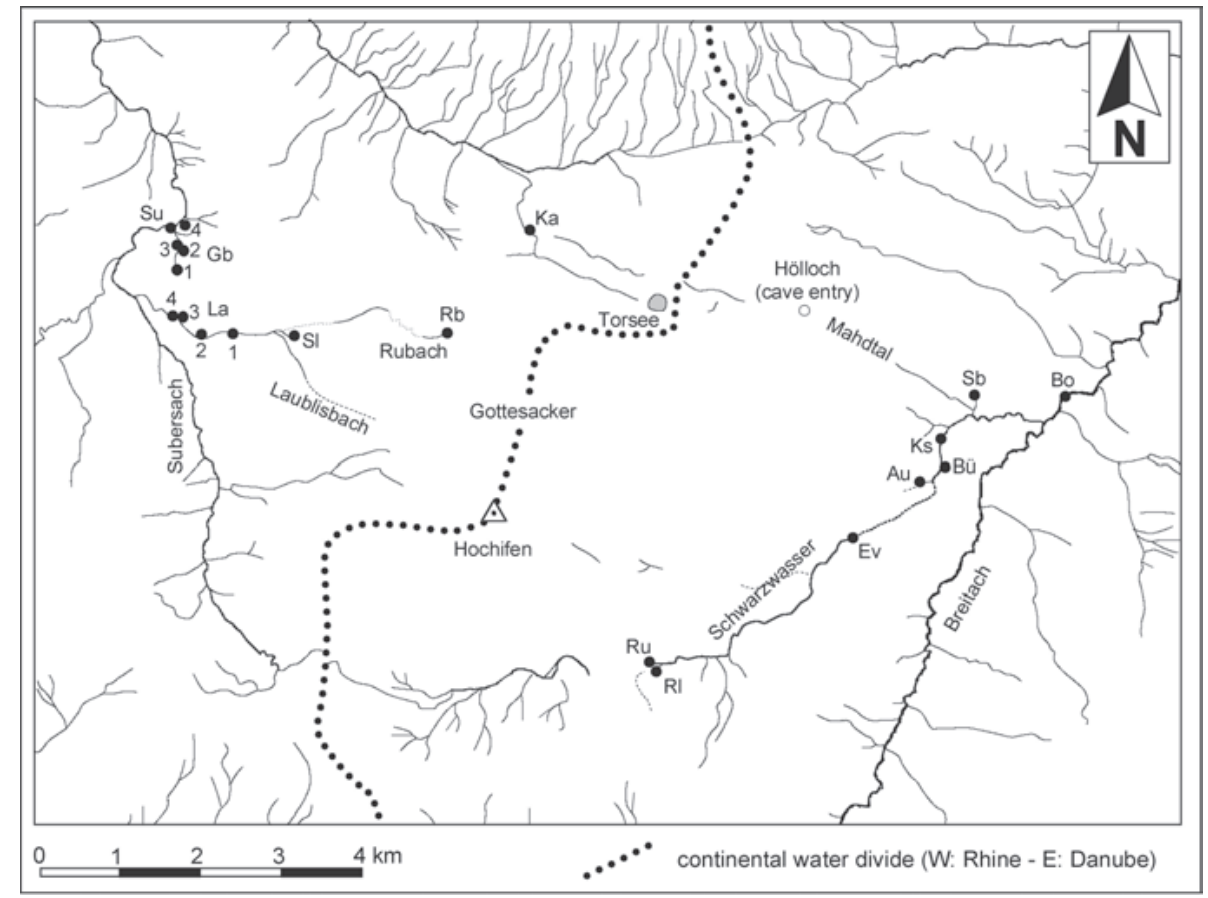

Fig. 5. Important springs (with shorthand symbol) and surface waters in the area.
Tab. 1. Overview of the important springs in geographical order and decreasing altitude. The term complex is used for confirmed interaction between different aquifer types and for unclear situations.

\begin{tabular}{|c|c|c|c|c|c|}
\hline Area & Name of the spring & Symbol & \begin{tabular}{|c|}
$\begin{array}{c}\text { Altitude } \\
{[\mathrm{m}]}\end{array}$ \\
\end{tabular} & $\begin{array}{c}\text { Discharge } \\
{[\mathrm{L} / \mathrm{s}]}\end{array}$ & $\begin{array}{c}\begin{array}{c}\text { Aquifer } \\
\text { type }\end{array} \\
\end{array}$ \\
\hline \multirow{8}{*}{$\begin{array}{l}\text { South } \\
\text { and } \\
\text { East }\end{array}$} & upper resurgence & $\mathrm{Ru}$ & 1280 & $0-2500$ & rockfall \\
\hline & lower resurgence & RI & 1280 & $6-70$ & rockfall \\
\hline & estavelle & Ev & 1120 & -500 to 4000 & karst \\
\hline & Aubach spring & $\mathrm{Au}$ & 1080 & $0-6000$ & karst \\
\hline & Bürgermeister spring & Bũ & 1040 & 40 & karst \\
\hline & Kesselschwand spring & Ks & 1050 & 15 & karst \\
\hline & Sägebach spring & $\mathrm{Sb}$ & 1035 & $150-2000$ & karst \\
\hline & bottom spring Breitach & Bo & 980 & 200 & karst \\
\hline North & Kessleralp spring & $\mathrm{Ka}$ & 1440 & $10-60$ & karst \\
\hline \multirow{12}{*}{ West } & Rubach spring & $\mathrm{Rb}$ & 1600 & $10-200$ & karst \\
\hline & Rubach Lake spring & Ls & 1490 & $30-50$ & complex \\
\hline & Schneckenlochbach spring & $\mathrm{SI}$ & 1220 & $10-1000$ & karst \\
\hline & Laublisbach spring 1 & La1 & 1070 & $3-20$ & karst \\
\hline & Laublisbach spring 2 & La2 & 1040 & $1-4$ & karst \\
\hline & Laublisbach spring 3 & La3 & 1025 & $5-50$ & complex \\
\hline & Laublisbach spring 4 & La4 & 1025 & 5 & complex \\
\hline & Goldbach spring 1 & Gb1 & 1010 & $42-82$ & complex \\
\hline & Goldbach spring 2 & Gb2 & 990 & $4-56$ & porous \\
\hline & Goldbach spring 3 & Gb3 & 990 & $70-246$ & karst \\
\hline & Goldbach spring 4 & Gb4 & 980 & 4-151 & porous \\
\hline & spring near Subersach river & Su & 960 & $15-46$ & karst \\
\hline
\end{tabular}

In large parts of the elevated areas, all rain and melt waters rapidly infiltrate into the karst aquifer; surface waters are absent. However, the limestone is locally covered by sandstone and marl in the cores of synclines or eroded along the crests of anticlines. In these settings, there are surface streams, e.g. in the western sections of anticline $\mathrm{V}$ and syncline V/VI. These streams often sink underground when they reach karst limestone. Lake Torsee is located on top of Drusberg marl in the core of anticline $\mathrm{V}$, near its culmination and on an important strike-slip fault (Fig. 4). The lake drains via two swallow holes into the adjacent karst aquifer.

The situation is more complex in the southeastwardly bordering Schwarzwasser valley, where the karst limestone plunges under the Flysch nappes. This geological asymmetry leads to a hydrological asymmetry: The Flysch Mountains at the SE side of the valley drain by surface runoff, while the karst area at the NW side drains underground. The river thus recieves surface inflow from several streams from the SE side but no surface inflow from the NW side. Consequently, there are two flow-systems in the valley: the surface river that drains the SE side of the valley and the underground karst water flow-system.

The valley is characterised by alternation of gorges and wide valley floors. The gorges are situated in the anticlines, where the river cuts the limestone. The Schwarzwasser River has its source at the continental water divide, flows over marl and sandstone, and over the alluvial plain upstream from the rockfall mass. At $1340 \mathrm{~m}$, it sinks into the rockfall via swallow holes. At the lower end of the rockfall, there are two neighbouring groups of springs at $1280 \mathrm{~m}$, the upper and lower resurgences $(R u, R l)$. In the middle section of the valley, anticline IV plunges under the valley so that the karst limestone outcrops and is cut by the river, forming a gorge. During lowflow conditions, the river sinks into a cave entrance in this gorge at $1120 \mathrm{~m}$ so that the channel is dry downstream from this point. During high-flow, the cave entrance transforms into a spring with a discharge of up to $4 \mathrm{~m}^{3} / \mathrm{s}$. The cave is thus an estavelle $(E v)$, probably one of the largest in the Alps (Goldscheider et al. 1999). It connects the surface river with the underground flow-system. 


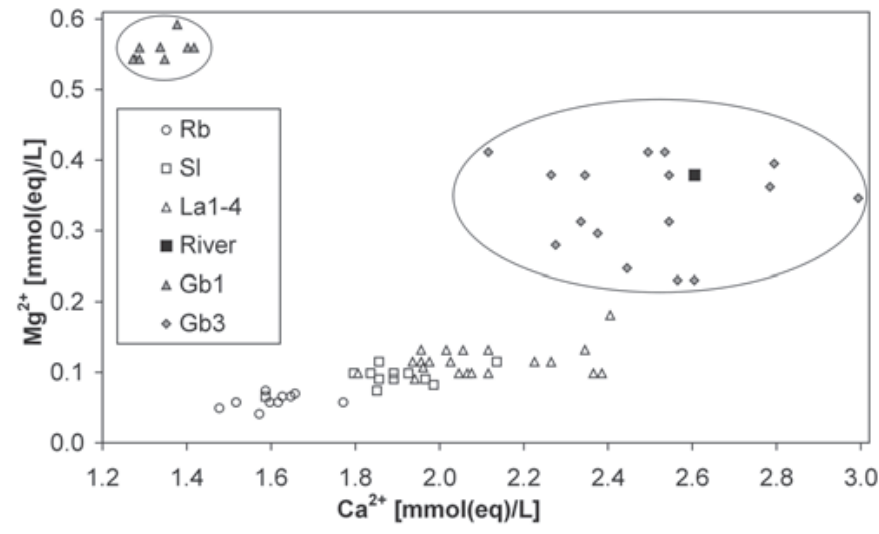

Fig. 6. Calcium and magnesium concentrations of the spring waters in the westward plunging syncline IV/V $(R b, S l, L a 1-4)$, the Subersach River and the Goldbach springs $1(G b 1)$ and $3(G b 3)$. The springs in the syncline show a systematic hydrochemical evolution. Goldbach spring 3 could be a mixture between karst water and river water. Goldbach spring 1 cannot be explained by mixing of the other components.

Further downstream, anticline $\mathrm{V}$ plunges under the valley and the limestone outcrops again. Three springs are located there: the large but non-permanent Aubach spring ( $A u$, $1080 \mathrm{~m}$ ) consists of several outlets and discharges up to $6 \mathrm{~m}^{3} / \mathrm{s}$. The Bürgermeister (Bü, $1050 \mathrm{~m}$ ) and Kesselschwand springs $(K s, 1040 \mathrm{~m})$ are smaller and permanent with a discharge of about 40 and $15 \mathrm{~L} / \mathrm{s}$ respectively. Downstream from these springs, the limestone is confined by sandstone and marl in the core of syncline V/VI, which forms the Mahdtal valley. At $1035 \mathrm{~m}$, the karst aquifer outcrops at a fault in a low topographic position. This is the location of the Sägebach spring $(\mathrm{Sb})$ that discharges up to about $2 \mathrm{~m}^{3} / \mathrm{s}$.

Below the confluence of the Schwarzwasser and Breitach River, the limestone outcrops in anticline VI. It was possible to detect a temperature anomaly that indicates upwelling of cold groundwater. By measuring the flow rate of the river upstream $\left(1.4 \mathrm{~m}^{3} / \mathrm{s}\right)$ and downstream $\left(1.6 \mathrm{~m}^{3} / \mathrm{s}\right)$ from this anomaly, the discharge rate of this invisible bottom spring $(B o)$ was determined: $0.2 \mathrm{~m}^{3} / \mathrm{s}$. As the spring is the lowest $(980 \mathrm{~m})$ direct outlet of the aquifer, the Breitach forms the hydrologic base level of the karst system.

The hydrologic situation is different in the western part of the area. The Subersach valley follows an axial depression, and there are folded Helvetic strata on both sides of the valley. The valley cuts through the karst limestone in the tight anticlines and thus isolates the synclines. The Subersach River has its source at the continental water divide. The upper section of the valley is a non-karst area. Further downstream, there is interaction between the karst aquifer and the river. On one hand, the river forms the local hydrologic base level of the karst system. On the other hand, flow measurements showed that the river loses 40-100 L/s by influent flow into the 'Iferwies' porous aquifer.

Syncline IV/V is the most important fold structure in the western Gottesacker. Karst limestone forms large parts of the land surface but is locally eroded near the trough of the syn- cline so that the underlying marl outcrops in an erosional window (Fig. 4). At the upper edge of this erosional window, the Rubach spring $(R b, 1600 \mathrm{~m})$ emerges near the base of the karst aquifer, giving rise to a stream. Downstream from the erosional window, it sinks back into the karst aquifer during low-flow conditions. During high-flow, however, it reaches the Subersach River. In the lower section of the syncline, there are five springs. The Schneckenlochbach spring $(S l, 1220 \mathrm{~m})$ is the main karst spring in this part of the area. Further down, near the Laublisbach stream, there are two karst springs above the valley floor ( $L a 1,1070 \mathrm{~m}$; La2, $1040 \mathrm{~m}$ ) and two springs emerging from gravel on the valley floor ( $L a 3$ and La4, $1025 \mathrm{~m}$ ). During low-flow conditions, all spring water seeps into the 'Iferwies' porous aquifer.

About $1 \mathrm{~km}$ to the $\mathrm{N}$, the Subersach valley cuts through the limestone in anticline V. Several springs are located in this part of the valley. Goldbach spring 1 (Gb1, $1010 \mathrm{~m}, 40-80 \mathrm{~L} / \mathrm{s})$ emerges from scree and block material; Gb3 $(990 \mathrm{~m}$, 70-250 L/s) emerges from karst limestone; a small karst spring near the Subersach River $(S u, 960 \mathrm{~m}, 10-50 \mathrm{~L} / \mathrm{s})$ is the lowest direct outlet of the karst system. The other springs are not relevant in this context.

\subsection{Hydrochemistry}

Water temperature and hydrochemistry were used as natural tracers to characterise the aquifer properties and obtain initial information about the spring catchments. The four karst springs in the Schwarzwasser valley show similar hydrochemical characteristics, indicating that they drain the same groundwater body. The water temperature is relatively low, about $5{ }^{\circ} \mathrm{C}$, which suggests inflow from higher altitudes, i.e. from the Gottesacker. Hydrochemical data also made it possible to better characterise the relations between the groundwater in the rockfall mass, surface water from the Flysch, and karst groundwater (Sinreich et al. 2002).

Natural tracers made it possible to better understand flow and mixing processes within the westward plunging syncline IV/V, and to characterise the complex interaction between the karst aquifer, the 'Iferwies' porous aquifer, the Subersach River, and springs $G b 1$ and $G b 3$. Within the syncline, $\mathrm{Ca}$ and $\mathrm{Mg}$ concentrations increase with decreasing altitude, i.e. increasing groundwater temperature and travel time (Fig. 6). Flow-measurements showed that the Subersach River loses water upstream from $G b 3$, and the concentrations measured at this spring indicate mixing of groundwater and river water. The hydrochemical characteristics of $G b 1$ are completely different and cannot be explained by mixing of the other components.

\section{Tracer tests}

\subsection{Overview}

Early tracer tests showed a connection between the Hölloch cave and the Sägebach spring (Spöcker 1961) and local flow 


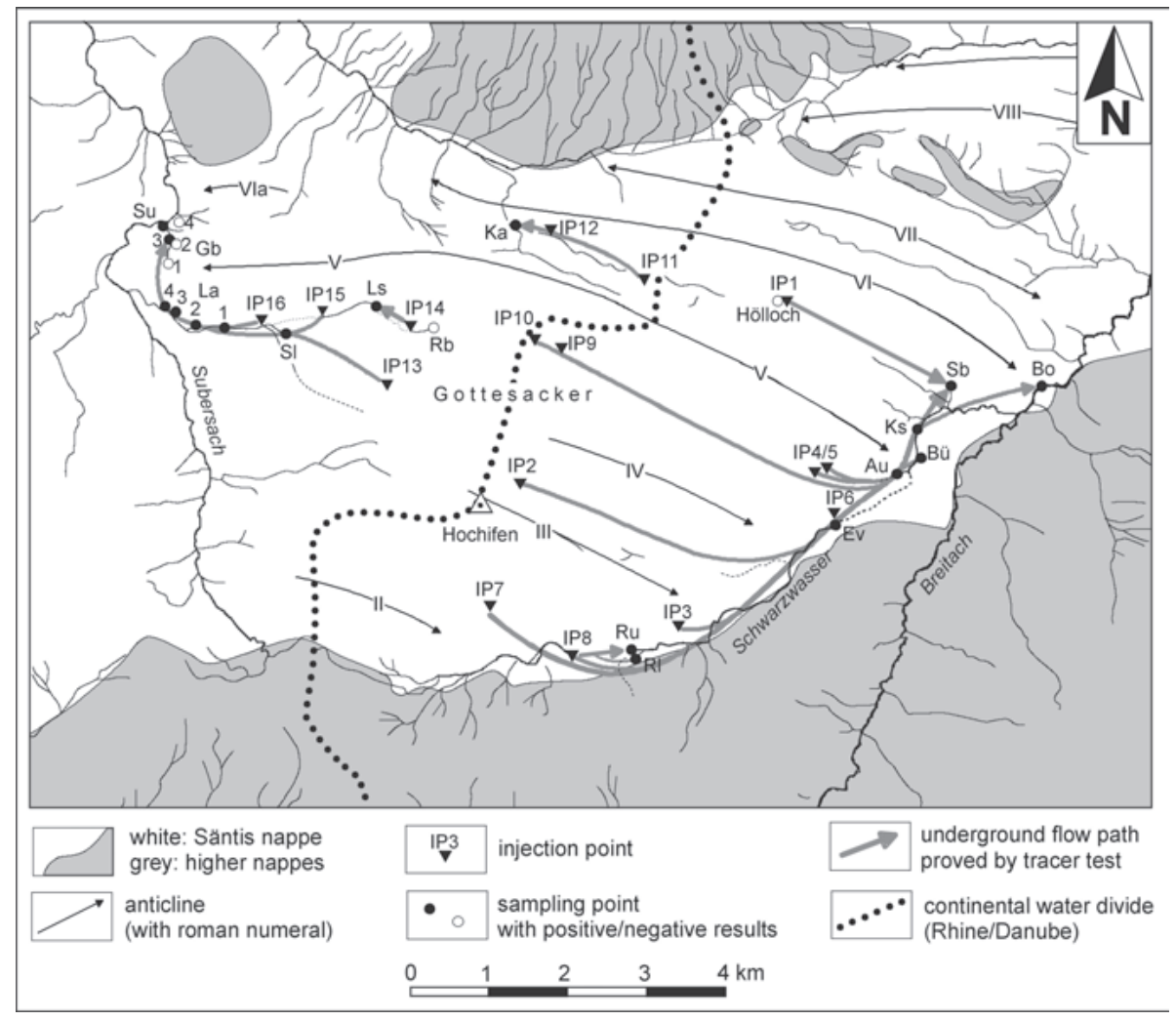

Fig. 7. Fold structures and flow paths confirmed by tracer tests in the Hochifen-Gottesacker area. The Hölloch cave stream served as an injection point for tracer test IP1 and as a sampling point during tracer test IP11. The estavelle (Ev) served as injection point for tracer test IP6 when it acted as a swallow hole and as a sampling point during many other tracer tests when it acted as a spring.
Tab. 2. Overview of the tracer injections in the Hochifen-Gottesacker area.

\begin{tabular}{|c|l|c|c|c|c|}
\hline No. & \multicolumn{1}{|c|}{ Description, geological setting } & Date & Tracer & $\begin{array}{c}\text { Mass } \\
{[\mathrm{kg}]}\end{array}$ & $\begin{array}{c}\text { Flushing } \\
\text { water }\end{array}$ \\
\hline IP1 & Holloch cave, syncline V/VI - E (Spöcker 1961) & $1949 / 55$ & Uranine & $1.8-10$ & - \\
IP2 & Sewage shaft, syncline III/IV - E & 20.09 .96 & Uranine & 4.80 & $10 \mathrm{~m}^{3}$ \\
IP3 & Doline, Schwarzwasser valley & 20.09 .96 & Eosin & 5.00 & - \\
IP4 & Ladstatt cave, Schwarzwasser valley & 14.08 .97 & Sulfo B & 0.70 & $1 \mathrm{~m}^{3}$ \\
IP5 & Doline, Schwarzwasser valley & 14.08 .97 & Eosin & 0.60 & $1 \mathrm{~m}^{3}$ \\
IP6 & Estavelle, cave entrance, Schwarzwasser valley & 14.08 .97 & Uranine & 0.20 & - \\
IP7 & Swallow hole, syncline II/III - E & 11.09 .97 & Eosin & 5.84 & - \\
IP8 & Sink of Schwarzwasser River into rockfall & 12.09 .97 & Sulfo B & 3.00 & - \\
IP9 & Central Gottesacker, syncline IVN - E of culmin. & 12.09 .97 & Uranine & 1.00 & $400 \mathrm{~L}$ \\
IP10 & Central Gottesacker, syncline IVN - W of culmin. & 12.09 .97 & Uranine & 2.00 & $400 \mathrm{~L}$ \\
IP11 & Swallow hole Lake Torsee, syncline V/VI - culmin. & 12.09 .97 & Pyranine & 3.70 & - \\
IP12 & Swallow hole, syncline V/VI - W & 12.09 .97 & Eosin & 0.37 & - \\
IP13 & Karst shaft near Wasenkopf, syncline IV/N - W & 12.09 .97 & Eosin & 4.00 & $800 \mathrm{~L}$ \\
IP14 & Swallow hole, limestone bank in Drusberg marl & 12.09 .97 & Pyranine & 2.00 & - \\
IP15 & Swallow hole, syncline IVN - W & 12.09 .97 & Sulfo B & 3.00 & - \\
IP16 & Laublisbach stream & 12.09 .97 & Napht. & 3.45 & - \\
\hline
\end{tabular}

paths within caves (Wagner 1950, Krieg 1969). However, there were no large-scale tracer tests before 1996. The research activities presented in this paper included three multi-tracer tests with a total of 15 injection points (IP2-16 in Tab. 2 and Fig. 7). The goal of these experiments was to understand the underground drainage pattern of the alpine karst aquifer system and the mechanisms of contaminant transport.

Furthermore, a comparative tracer test with 10 different substances was carried out. The tracers were injected simultaneously into the same swallow hole in order to compare their transport behaviour (Goldscheider et al. 2001). Sinreich et al. (2002) carried out a small salt-tracer test in the rockfall mass. The results from these experiments are not presented here.

\subsection{Experimental design}

In order to get a complete picture of the underground flow paths of the entire karst system, at least one injection point was selected in each syncline, both $\mathrm{E}$ and $\mathrm{W}$ of the culmination line. Three injection points are located near the culmination line in order to better localise the continental water divide (IP9-11). The injections in the Schwarzwasser valley (IP3-7) aimed at better characterisation of the underground flow system along the valley axis; IP8 is the sink of the river into the rockfall mass in the upper section of the valley. Two injections additionally aimed at assessing the impact of specific hazards on the groundwater: the sewage shaft of a ski station (IP2) and a cave filled with waste (IP4) (Goldscheider 2000).

Five injection points are located within the western section of syncline IV/V: IP10 is located in its uppermost section, only about $100 \mathrm{~m}$ west of the culmination; IP15 is located in the trough of the syncline; IP13 on its southern limb; and IP14 is within the erosional window. There, the tracer was injected into a karstified limestone bank within the Drusberg marl, where the Rubach stream often sinks underground. Another tracer was injected into the Laublisbach stream (IP16) in order to check connection with the springs in the valley. These five injections aimed at better understanding the complex interaction between surface water and the karst aquifer, and on delineating the catchments of the Goldbach springs, which could potentially be used for drinking water supply. 


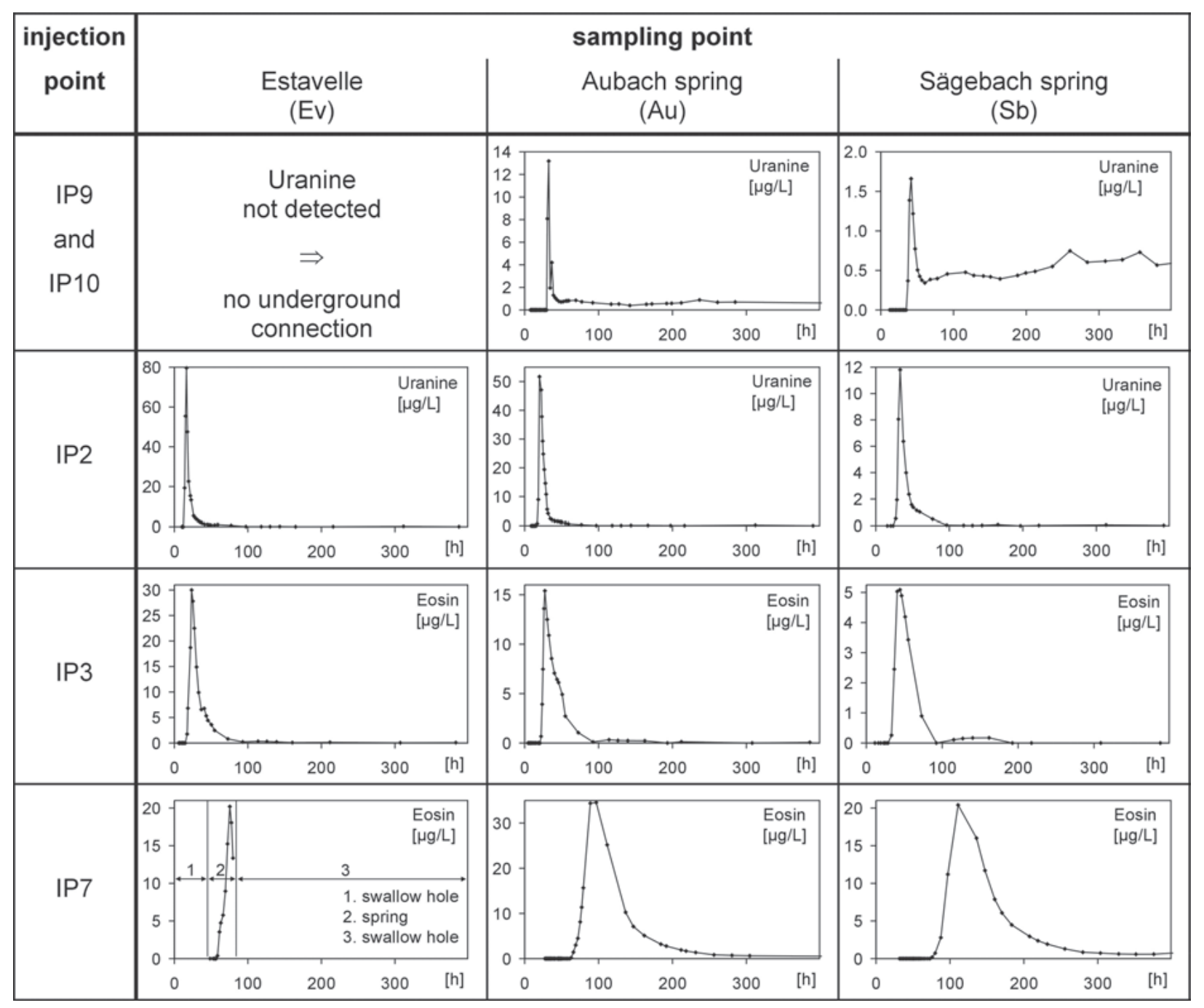

Fig. 8. Selected breakthrough curves from different multi-tracer tests in the eastern part of the area. The curves of the springs $B \ddot{u}$ and $K s$ are similar to those of $A u$ and are not presented here.

At most of the injection points, there was naturally flowing water. For some injections, however, flushing water had to be provided (Tab. 2). Fluorescence dyes were used as tracers because of their favourable properties: uranine, eosin, sulforhodamine B, pyranine, and naphthionate (Käss 1998). After the injections, water samples were taken manually or with automatic samplers at all relevant springs, in the Hölloch cave stream (Sep 97), the Schwarzwasser River up- and downstream from the estavelle, and the Breitach River upstream, directly at, and downstream from the bottom spring. Charcoal bags were installed in small springs and sampling sites in streams. The observation periods lasted up to 60 days.

\subsection{Selected results}

Fig. 7 shows the flow paths as indicated by tracer tests in relation with the fold structures. Selected tracer breakthrough curves from the $\mathrm{E}$ and $\mathrm{W}$ part of the area are presented in Figs. 8 and 9. Tab. 3 summarises the results. The tracer injections in the Schwarzwasser valley documented the existence of a continuous groundwater flow-system along the valley axis. The tracers that were injected in the middle and upper section of the valley (IP3, IP7) arrived at the estavelle $(E v)$, which temporarily acted as a spring, and at the karst springs in the lower section of the valley $(A u, B \ddot{u}, K s, S b)$. Proving tracer arrival at the bottom spring $(B o)$ in the Breitach River was difficult, as the river receives inflow from all springs upstream. However, the tracer concentrations downstream from the bottom spring were temporarily higher than upstream. The tracer that was injected into the estavelle (IP6), which acted as a swallow hole at this time, arrived at all springs in the lower section of the valley.

The tracer injections in all synclines $\mathrm{E}$ of the culmination line further document the important influence of the folds on 


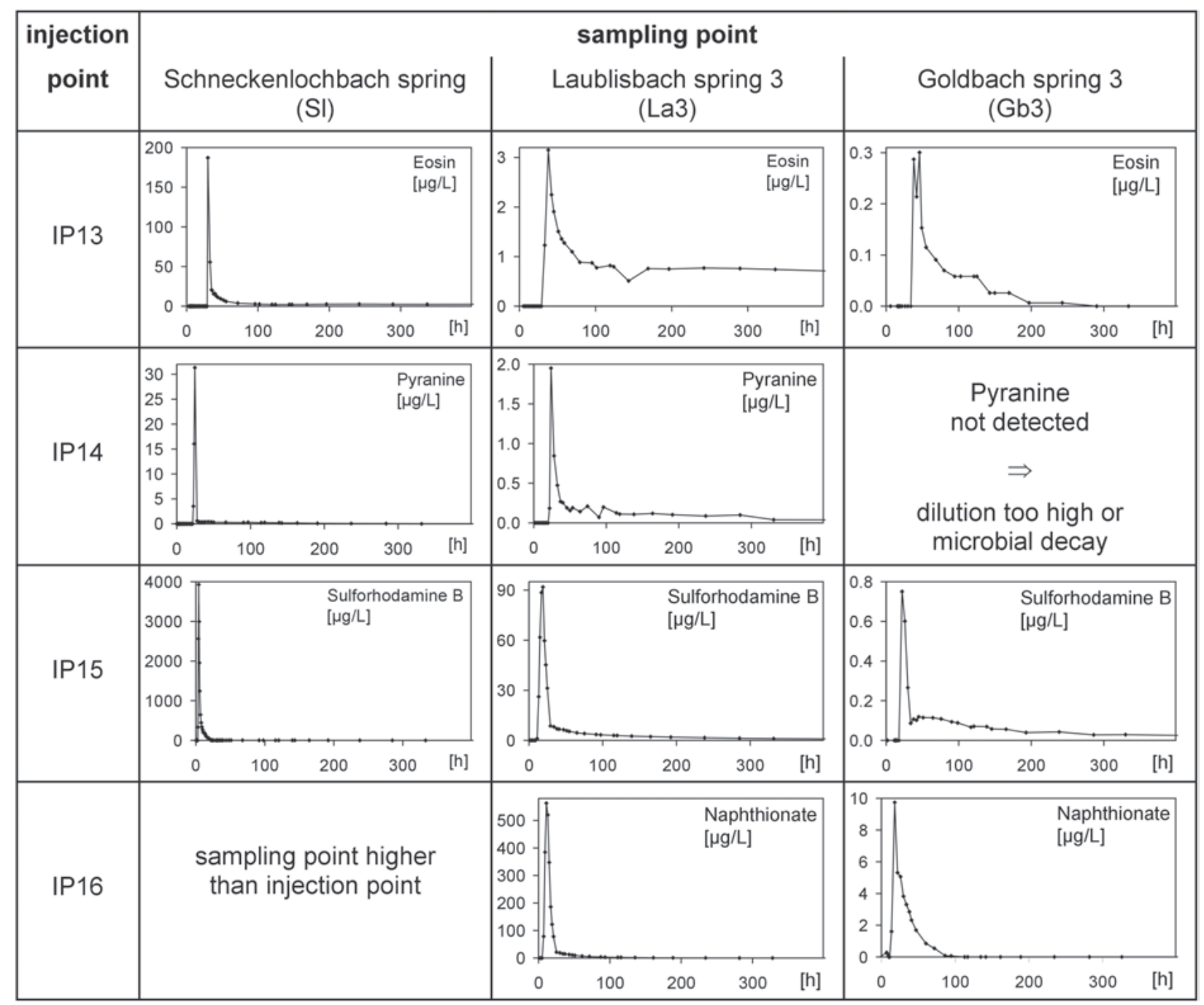

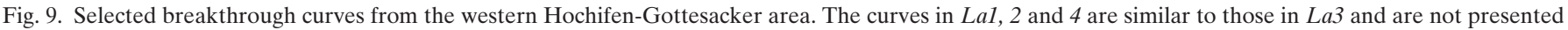
here; minor traces of Sulforhodamine were detected at $S u$; no positive results were obtained for $R b, G b 1,2$ and 4 .

the underground drainage. The tracer that was injected into syncline V/VI (IP1) reached the Sägebach spring but not the Aubach spring (Spöcker 1961). The underground flow path thus seems to follow the trough of this syncline. The southward bordering syncline IV/V plunges under the valley floor downstream from the estavelle but upstream from the Aubach spring. The tracer that was injected in this syncline $100 \mathrm{~m}$ E of the culmination line (IP9) arrived at the Aubach spring and the other springs further downstream but did not reach the estavelle. This result confirms underground flow along the syncline axis. The tracers that were injected into syncline III/IV (IP2) and II/III (IP7) first reached the estavelle and then the karst springs further down the valley. IP7 also confirms flow in the karst aquifer below the rockfall. No trace of these dyes was detected in the river upstream from the estavelle, which confirms that the river gets no inflow from the karst system on the NW side but is fed by tributaries from the Flysch area on the SE side.
The tracer that was injected in the sink of the Schwarzwasser River into the rockfall mass (IP8) allowed characterisation of the hydrogeological properties of this coarse-grained, heterogeneous porous aquifer, which shows similarities to a karst aquifer (Sinreich et al. 2002). The tracer also arrived at the estavelle and the karst springs further downstream, proving that the karst aquifer drains the overlying rockfall.

Injections IP9-11 made it possible to more closely identify the location of the continental groundwater divide. The tracers that were injected $100 \mathrm{~m} \mathrm{E}$ (IP9) and $100 \mathrm{~m} \mathrm{~W}$ (IP10) of the culmination point of the axis of syncline IV/V both arrived at the karst springs to the $\mathrm{E}$ but were not detected at the Rubach spring $(R b)$ or any other spring to the $\mathrm{W}$. The continental water divide thus runs at least $100 \mathrm{~m} \mathrm{~W}$ of the culmination line in this part of the area. In contrast, the tracer injected in the swallow holes of Lake Torsee (IP11) reached the spring that drains the $\mathrm{W}$ section of syncline V/VI $(K a)$ but was not detected in the 


\begin{tabular}{|c|c|c|c|c|c|c|c|c|c|c|c|c|c|c|c|c|c|}
\hline \multirow{2}{*}{$\begin{array}{c}\text { area } \\
\downarrow \\
\end{array}$} & \multirow{2}{*}{$\begin{array}{c}\longrightarrow \\
\text { spring } \\
\text { no. }\end{array}$} & \multicolumn{9}{|c|}{ South and East } & \multicolumn{2}{|c|}{ North } & \multicolumn{4}{|c|}{ West } & \multirow{2}{*}{$\begin{array}{c}\mathbf{t}_{\mathrm{m}} \\
\mathrm{c} / \mathrm{M}\end{array}$} \\
\hline & & IP1*I & IP2 & |IP3 & IP4 & |IP5| & |IP6 & |IP7 & $\begin{array}{l}\text { injec } \\
\text { IP8 }\end{array}$ & $\begin{array}{l}\text { tion poi } \\
\mid \text { IP9+10 }\end{array}$ & $\begin{array}{l}\text { nt } \\
\mid \text { |IP11| }\end{array}$ & | IP12 & |IP13 & |IP14 & |IP15 & |IP16|| & \\
\hline \multirow{10}{*}{$\begin{array}{c}\text { South } \\
\text { and } \\
\text { East }\end{array}$} & $\mathrm{Ru}$ & & - & - & & & & - & $\begin{array}{c}11 \\
121\end{array}$ & & & & & & & & $\begin{array}{c}\mathrm{h} \\
10^{-6} \mathrm{~m}^{-3}\end{array}$ \\
\hline & $\overline{\mathrm{RI}}$ & & - & - & & & & - & \begin{tabular}{|c|}
36 \\
0.85 \\
\end{tabular} & & & & & & & & $\begin{array}{c}\mathrm{h} \\
10^{-6} \mathrm{~m}^{-3} \\
\end{array}$ \\
\hline & Ev & & \begin{tabular}{|l|}
17 \\
17
\end{tabular} & \begin{tabular}{|l|}
23 \\
6.0
\end{tabular} & & & $\begin{array}{c}= \\
\text { IP6 }\end{array}$ & \begin{tabular}{|l|}
75 \\
3.5
\end{tabular} & $\begin{array}{l}38 \\
6.1\end{array}$ & $\overline{-}$ & & & & & & & $\begin{array}{c}\mathrm{h} \\
10^{-6} \mathrm{~m}^{-3}\end{array}$ \\
\hline & $\overline{\mathrm{Au}}$ & - & 20 & 25 & 81 & \begin{tabular}{|l|}
32 \\
325
\end{tabular} & \begin{tabular}{|l|}
12 \\
7
\end{tabular} & 97 & 45 & 33 & - & & & & & & $\begin{array}{c}\mathrm{h} \\
\mathrm{c}^{-6} \mathrm{~m}^{-3}\end{array}$ \\
\hline & Bü & & $\begin{array}{l}11 \\
22 \\
\end{array}$ & \begin{tabular}{|l|}
3.1 \\
31
\end{tabular} & $\begin{array}{c}0.36 \\
81\end{array}$ & \begin{tabular}{|l|}
3.5 \\
33 \\
\end{tabular} & \begin{tabular}{|l|}
70 \\
13 \\
\end{tabular} & $\begin{array}{l}5.9 \\
97\end{array}$ & $\frac{2.6}{45}$ & $\begin{array}{c}\frac{4.4}{32} \\
\end{array}$ & - & & & & & & $\frac{10 \mathrm{~m}}{\mathrm{~h}}$ \\
\hline & & & 8.2 & 2.6 & 0.35 & 3.3 & 68 & 5.9 & 2.5 & 6.6 & & & & & & & $10^{-6} \mathrm{~m}^{-3}$ \\
\hline & Ks & & & & $\begin{array}{c}81 \\
0.33\end{array}$ & \begin{tabular}{|c|}
37 \\
3.2
\end{tabular} & \begin{tabular}{|l|}
15 \\
61
\end{tabular} & $\begin{array}{l}97 \\
5.4\end{array}$ & $\begin{array}{l}46 \\
2.1\end{array}$ & $\begin{array}{l}35 \\
3.4\end{array}$ & - & & & & & & $\begin{array}{c}\mathrm{h} \\
10^{-6} \mathrm{~m}^{-3}\end{array}$ \\
\hline & $\mathrm{Sb}$ & $61^{*}$ & 33 & 44 & 107 & 56 & 31 & 111 & 55 & 42 & - & & & & & & $\mathrm{h}$ \\
\hline & & & 2.5 & 1.0 & 0.31 & 2.5 & 31 & 3.5 & 0.85 & 0.55 & & & & & & & $10^{-6} \mathrm{~m}^{-3}$ \\
\hline & Bo & & + & + & + & + & + & + & + & + & & & & & & & \\
\hline North & $\mathrm{Ka}$ & & & & & & & & & & $\begin{array}{l}29 \\
48 \\
\end{array}$ & \begin{tabular}{|c|}
11 \\
4452 \\
\end{tabular} & & & & & $\begin{array}{c}\mathrm{h} \\
10^{-6} \mathrm{~m}^{-3}\end{array}$ \\
\hline \multirow{14}{*}{ West } & $\mathrm{Rb}$ & & & & & & & & & - & & & & - & & & \\
\hline & LS & & & & & & & & & - & & & & $\begin{array}{l}22 \\
52\end{array}$ & & & $\begin{array}{c}\mathrm{h} \\
10^{-6} \mathrm{~m}^{-3}\end{array}$ \\
\hline & SI & & & & & & & & & - & & & $\begin{array}{l}30 \\
47\end{array}$ & $\begin{array}{l}24 \\
16\end{array}$ & \begin{tabular}{|c|}
4 \\
2980
\end{tabular} & & $\begin{array}{c}\mathrm{h} \\
10^{-6} \mathrm{~m}^{-3}\end{array}$ \\
\hline & La1 & & & & & & & & & - & & & $\begin{array}{c}33 \\
0.53\end{array}$ & $\begin{array}{l}26 \\
2.6\end{array}$ & \begin{tabular}{|c|}
12 \\
393 \\
\end{tabular} & \begin{tabular}{|c||}
6 \\
910
\end{tabular} & $\begin{array}{c}\mathrm{h} \\
10^{-6} \mathrm{~m}^{-3}\end{array}$ \\
\hline & La2 & & & & & & & & & - & & & $* \star$ & 40 & 25 & 21 & $\mathrm{~h}$ \\
\hline & & & & & & & & & & & & & 0.15 & 0.09 & 4.2 & 32 & $10^{-6} \mathrm{~m}^{-3}$ \\
\hline & La3 & & & & & & & & & - & & & 38 & 24 & 19 & 11 & $\mathrm{~h}$ \\
\hline & & & & & & & & & & & & & 23 & 0.975 & 70 & 164 & $10^{-6} \mathrm{~m}^{-3}$ \\
\hline & La4 & & & & & & & & & - & & & \begin{tabular}{|c|}
33 \\
0.63 \\
\end{tabular} & $\begin{array}{c}28 \\
0.335\end{array}$ & $\begin{array}{l}17 \\
41\end{array}$ & $\begin{array}{c}13 \\
102\end{array}$ & $\begin{array}{c}\mathrm{h} \\
10^{-6} \mathrm{~m}^{-3}\end{array}$ \\
\hline & Gb1 & & & & & & & & & - & & & - & - & - & - & \\
\hline & $\mathrm{Gb} 2$ & & & & & & & & & - & & & - & - & - & - & \\
\hline & Gb3 & & & & & & & & & - & & & \begin{tabular}{|c|}
46 \\
0.08 \\
\end{tabular} & + & \begin{tabular}{|c|}
22 \\
0.57 \\
\end{tabular} & $\begin{array}{r}18 \\
3.3 \\
\end{array}$ & $\begin{array}{c}\mathrm{h} \\
10^{-6} \mathrm{~m}^{-3} \\
\end{array}$ \\
\hline & Gb4 & & & & & & & & & - & & & - & - & - & - & \\
\hline & $\mathrm{Su}$ & & & & & & & & & - & & & + & + & \begin{tabular}{|c|}
76 \\
0.04 \\
\end{tabular} & + & $\begin{array}{c}\mathrm{h} \\
10^{-6} \mathrm{~m}^{-3}\end{array}$ \\
\hline
\end{tabular}

Tab. 3. Overview of tracer test results in the test site area. The times of maximum concentration $\mathrm{t}_{\mathrm{m}}[\mathrm{h}]$ and the normalised maximum concentrations c/M $\left[10^{-6} \mathrm{~m}^{-3}\right]$ are given for each breakthrough curve. Symbols: + no tracer breakthrough curve but indirect evidence for connection, - negative result, * only the time of first visible detection is given by Spöcker 1961, ** curve shows no clear maximum. Grey: connection impossible for topographic and hydrogeological reasons.
Hölloch cave stream or any other sampling point to the E. The lake thus drains towards the $\mathrm{W}$, and the continental water divide largely coincides with topography in this part of the area.

The tracers that were injected at different points within syncline IV/V in the W part of the Gottesacker (IP13-15) reappeared at all springs in the lower section of this syncline $(\mathrm{Sl}$, La1-4) and, in very low concentrations, at Goldbach spring 3 (Gb3) and the small karst spring near the Subersach River (Su). No trace of the dyes was detected at Goldbach spring 1. In detail, the flow paths confirmed by these tracer tests are very complex, as there is intensive interaction between surface water and groundwater. The surfaces below the normalised tracer breakthrough curves (the integrals) can be used to quantify mixing and dilution processes in karst aquifers (Goldscheider 2002). Within syncline IV/V the values decrease exponentially from $\mathrm{Sl}$ to $\mathrm{La} 4$ dependent on the distance to the injection point (Fig. 10). This observation can be explained by regular dilution in the aquifer. At Goldbach spring 3, the value is only $6 \%$ of the value that could be expected by regular dilution. Thus, only a small proportion of the spring water was originated from the karst aquifer during the given hydrologic conditions. The rest of the water must come from elsewhere, probably from the 'Iferwies' porous aquifer.

Hydrologic conditions were extremely variable during the experiment in Sept. 1997. The night after the injections, a storm rainfall of $34 \mathrm{~mm}$ caused sudden change from low-flow to highflow conditions. The discharge of all springs increased within hours; the estavelle transformed from a swallow hole into a spring. The following weeks were a dry period, so the flow rates slowly decreased. The tracer breakthrough curves began with a sudden increase in concentration. After the following decrease, concentrations stayed on a relatively high level for several weeks. This can be explained by gradient-inversion in the aquifer (Cornaton \& Perrochet 2002): due to the sudden increase of hydraulic pressure in the conduits and the rise of the water table, water and tracers penetrated the fissured rock 


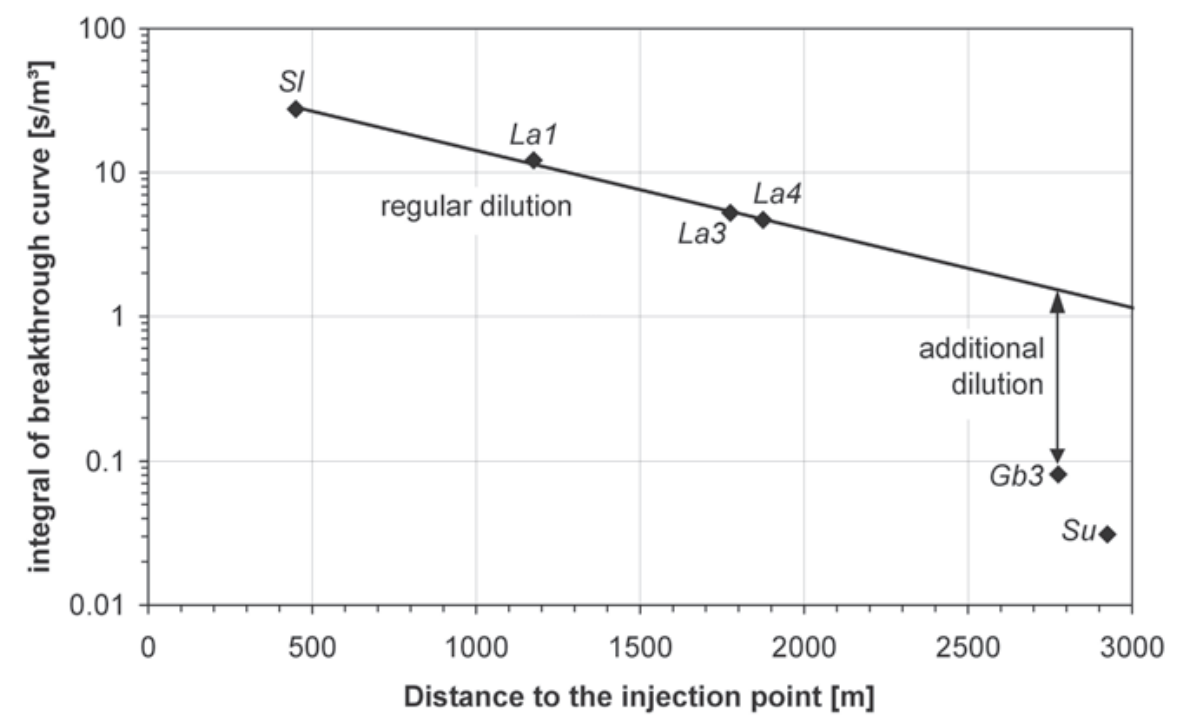

Fig. 10. Integrals of the normalised Sulforhodamine breakthrough curves (injection IP 15) at different springs: regular dilution between the springs $S l$ and $L a 4$; higher dilution by additional inflow at the spring $G b 3$.

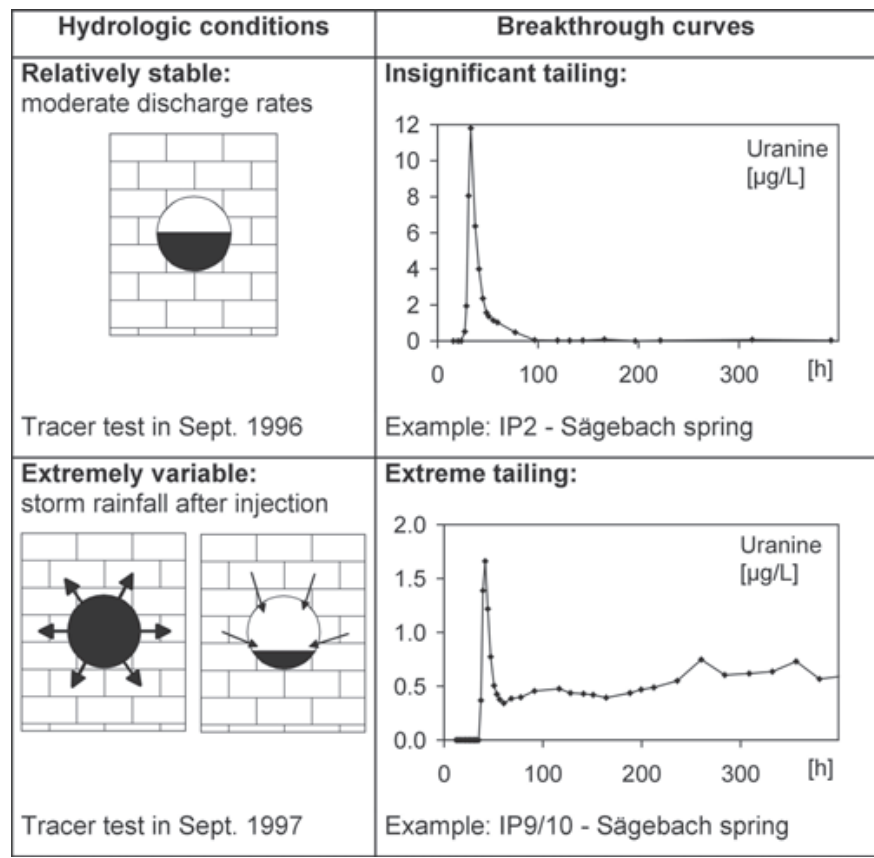

Fig. 11. Hydraulic interaction between karst conduits and the adjacent rock matrix for different hydrologic conditions and the resulting breakthrough curves.

matrix and the unsaturated zone. Later on, the conduits drained these zones again, slowly releasing the tracer (Fig. 11).

\section{Discussion and conclusions}

\subsection{Fold structure and underground drainage pattern}

The alpine karst system Hochifen-Gottesacker is characterised by a relatively thin karst aquifer, which is underlain and, local- ly, overlain by thick marl aquicludes. This high contrast in permeability and thickness between the aquifer and the aquicludes results in groundwater flow parallel to the stratification. In detail, cave patterns and groundwater flow paths often follow faults and fractures within the karst limestone, e.g. in the Hölloch cave. However, as the displacements of the faults are most often inferior to aquifer thickness, faults do not allow for significant flow across the stratification. This high degree of stratigraphic flow control is the precondition for flow control by the folds, which was demonstrated by 16 tracer tests.

In the elevated parts of the area, the base of the aquifer is above the local hydrologic base level (zone of 'shallow karst' as defined by Bögli, 1978). In this zone, the underground flow takes place near the base of the aquifer and follows the dip of the strata towards the troughs of the plunging synclines, which form the main drainage axes. The anticlines form local groundwater divides (Fig. 12). The continental drainage divide RhineDanube follows the culmination line of the fold axes, although it may locally differ by about $100 \mathrm{~m}$ (Fig. 13).

The interlimb angle of the folds also influences the drainage type. When the strata are gently folded, the karst limestone often forms the entire land surface and all drainage is underground. When the folds are closer, the limestone is often eroded along the anticlines, and covered by marl along the synclines. Surface streams may thus follow both anticline and syncline axes.

Two main valleys run across the folds: the Schwarzwasser valley follows the main thrust of the Flysch over the Säntis nappe, while the Subersach valley follows a strike-slip fault zone and an axial depression. The folds are tighter in the Subersach valley than in the Schwarzwasser valley, which has a major impact on the drainage pattern.

Along the entire Schwarzwasser valley, gently folded limestone is preserved, forming a continuous karst aquifer 


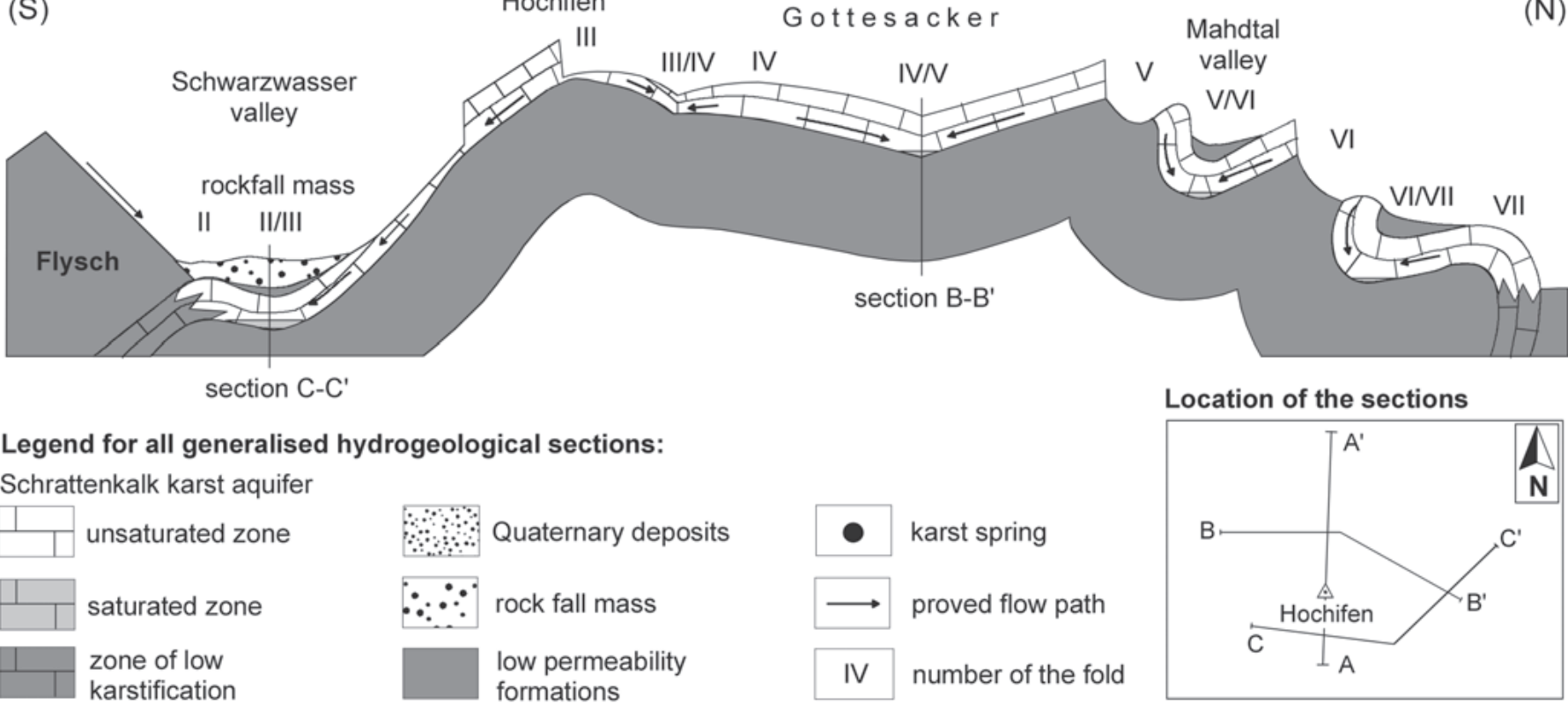

Fig. 12. Hydrogeological section of the Hochifen-Gottesacker area perpendicular to the fold axes, with the legend for and the location of all sections. The sections are generalised and the thickness of the karst aquifer is exaggerated in order to better show the relevant hydrogeological features.

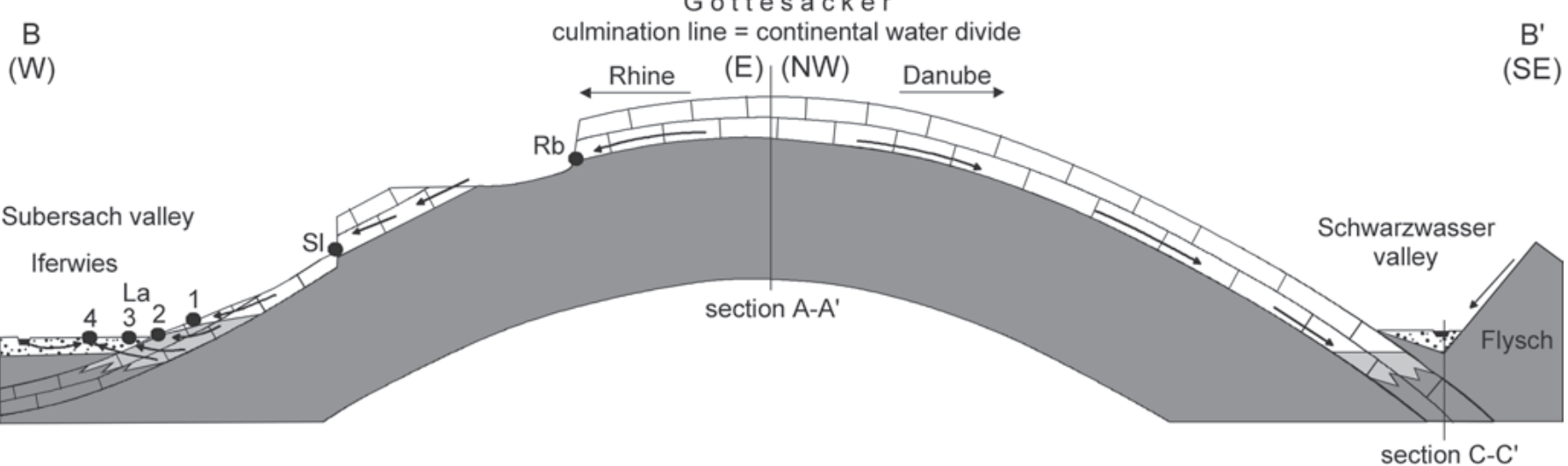

Fig. 13. Generalised hydrogeological section from the Subersach valley, over the Gottesacker to the Schwarzwasser valley along the axis (trough) of the main syncline (IV/V).

(Fig. 14). It collects groundwater from the NW side of the valley, as well as sinking and seeping surface waters from the SE side. As the base of the aquifer is below the valley floor, groundwater fills up the synclines and overflows the anticlines. Tracer tests confirmed flow along the valley axis, running across all folds. There is a systematic evolution of hydrologic features along the valley axis: In the upper section, there are no important karst springs but several sinking streams and swallow holes. In the middle section, there is an estavelle, which acts as a swallow hole during low-flow and transforms into a spring during high-flow conditions. In the lower section, there are four springs: a non-permanent spring and, further downstream, three permanent springs. The bottom spring in the Breitach River is the lowest outlet of the system, probably with a relatively stable discharge. The estavelle and the springs are located near the anticlines, where the karst aquifer outcrops. It is debatable whether the term 'deep karst', as defined by Bögli (1978), applies to this valley. On one hand, the base of the aquifer is below the valley floor. On the other hand, the local hydrologic base level, the Breitach River, is still below the Schwarzwasser valley. 


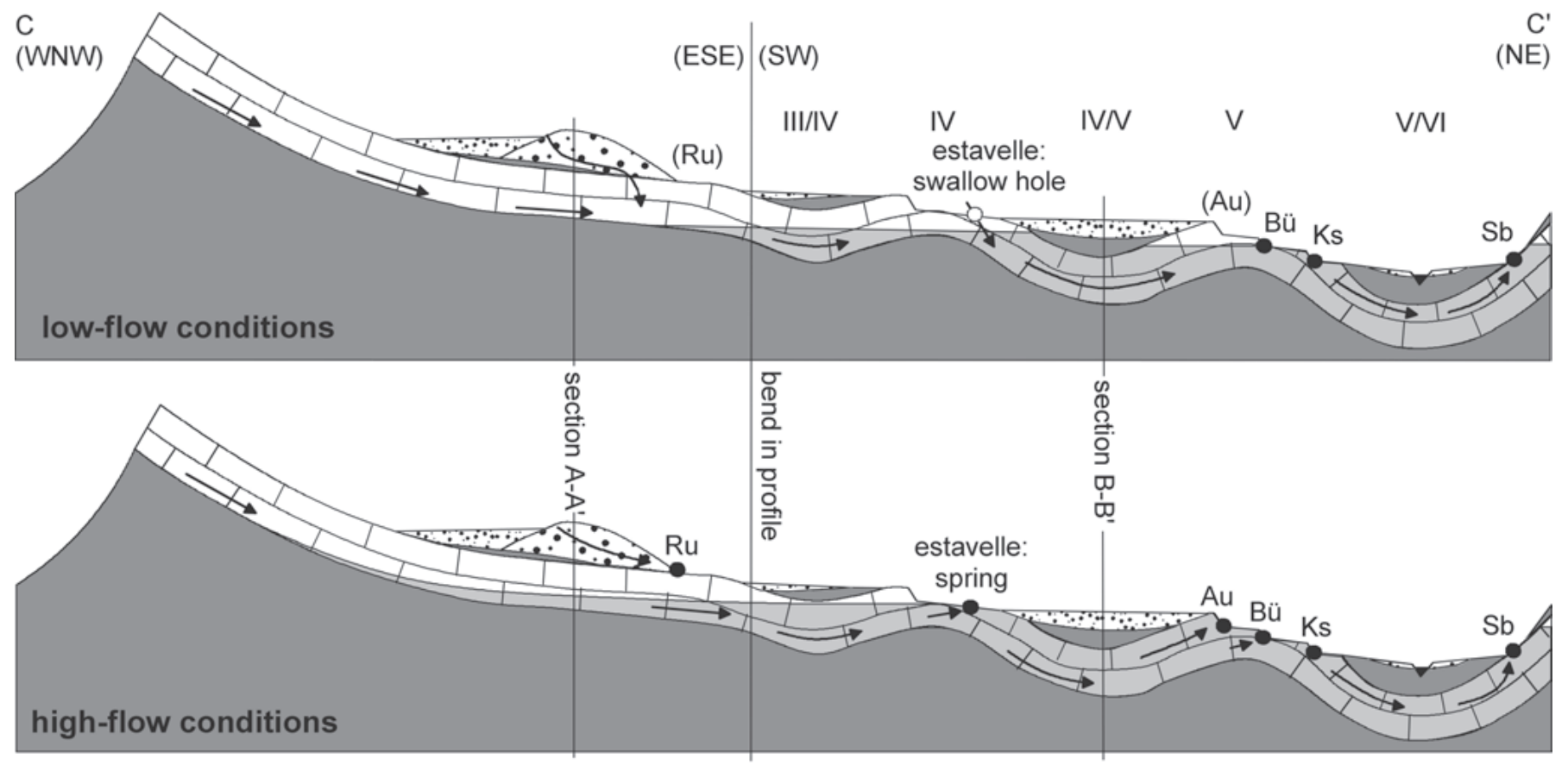

Fig. 14. Generalised hydrogeological section of the Schwarzwasser valley during low- and high-flow conditions. For legend see Fig. 12.

In the Subersach valley, the strata are closely folded so that the valley cuts through the limestone in the anticlines. There is no hydraulically connected karst aquifer in the valley, and the synclines represent largely isolated catchment areas. The most important one is syncline IV/V, which forms the entire western Gottesacker. In this syncline, the limestone is locally eroded so that the underlying marl is exposed. There is intensive change and interaction between surface flow on top of the marl and underground flow in the karst aquifer. The syncline is mainly drained by springs in its lower section, above or near the valley floor (Fig. 13). A small portion of the groundwater from this syncline flows toward spring $G b 3$, probably along a branch of a fault zone. In detail, the hydrogeological situation is highly complex in this area, as there is intensive interaction between the groundwater in the karst aquifer, the porous aquifer in the valley floor, the surface stream in the syncline, and the Subersach River. The western section of syncline V/VI also forms an isolated system, which is, however, relatively simple, as it is drained by one single karst spring.

The conceptual model shown in Fig. 15 illustrates schematically the relation between fold structures, surface and underground drainage pattern in alpine karst systems with strong stratigraphic flow-control, like the test site under investigation.

\subsection{Delineation of the catchment areas}

Due to strong stratigraphic flow control and flow control by the folds, the spring catchments can be delineated much more precisely than it is possible in other karst systems. This was done on the basis of geological and hydrological data and confirmed by 16 tracer tests. The culmination line separates the karst area into a western and an eastern part (Fig. 16). The E part forms a large, connected catchment that is drained by several springs. During high-flow conditions, when the estavelle acts as a spring, this catchment mainly consists of the karst area on the NW side of the Schwarzwasser valley. During lowflow conditions, all water from the Flysch area infiltrates into the karst aquifer via the estavelle and at several other points. The catchment then includes the SE side of the valley. The crests of the anticlines subdivide this large catchment into overlapping sub-catchments:

- The catchment of the bottom spring and spring $S b$ comprises the entire area.

- The catchment of the karst springs $A u, B \ddot{u}$ and $K s$ is the area south of anticline V.

- When the estavelle acts as a spring, its catchment consists of the area south of anticline IV.

- The catchment of the spring $R u$ below the rockfall mass includes the non-karst area in the upper section of the valley.

In the western part of the area, syncline IV/V forms a large catchment that consists of several sub-catchments with complex internal structure. The flow paths are highly variable dependent on the hydrologic conditions. One example for lowflow conditions, demonstrated by tracer tests and field observations: Water that infiltrates into the karst aquifer in the upper section of the syncline first reappears at the Rubach 


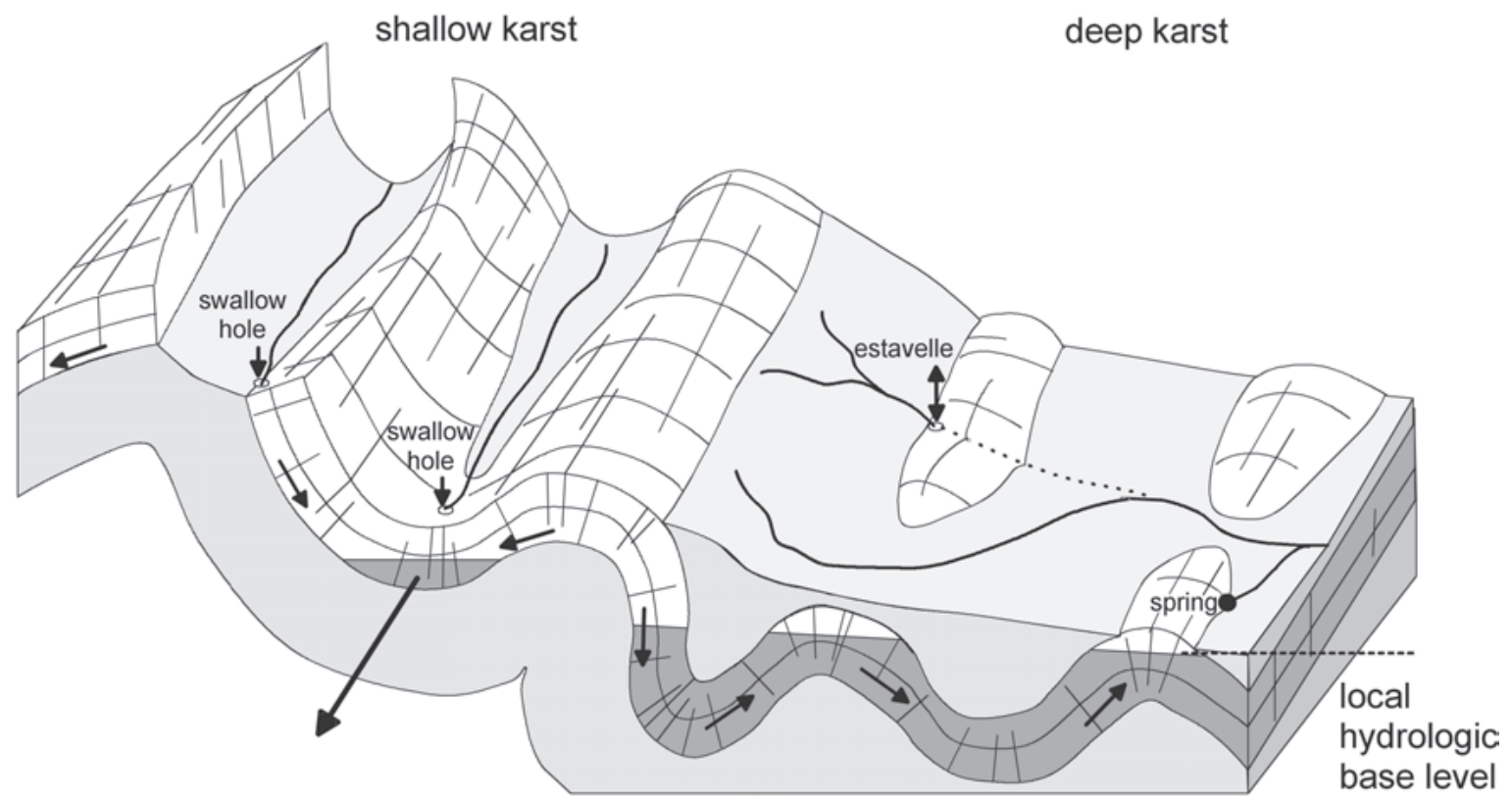

Fig. 15. Schematic illustration of the relation between fold structures, hydrologic base level, surface and underground drainage in an alpine karst system with strong stratigraphic flow control. Synclines form the main flow paths in the zone of shallow karst; flow across the folds is possible in the zone of deep karst.

spring $(R b)$. Further downstream, it sinks underground, reappears at the surface, and sinks into the aquifer. This alternation of sinking or seeping and reappearance is repeated up to six times before the water finally reaches the Subersach River. During high-flow conditions, however, there is a continuous stream from the uppermost spring down to the river. A part of this flow system is shown in the left (W) part of Fig. 13. Flow measurements and hydrochemical data suggest that spring $G b 3$ receives additional inflow from the Subersach River. The catchment of spring $K a$ consists of the W section of syncline V/VI and Lake Torsee.

\subsection{Hydraulic properties and vulnerability of the karst aquifer}

Linear groundwater flow velocities were calculated from tracer tests by dividing the distance between the injection point and the spring by the travel time of the tracer. These linear flow velocities are lower than the real velocities along complex flow paths. The highest linear velocity takes into account the time of the first tracer arrival; the dominant velocity takes the time of the maximum concentration. Typical velocities for karst groundwater range between 18 and $360 \mathrm{~m} / \mathrm{h}$ but may be as high as $1450 \mathrm{~m} / \mathrm{h}$ (Ford \& Williams 1989). The flow velocities in the test site are thus relatively high (Tab. 4). The highest velocities occur in the troughs of large synclines $(247 \mathrm{~m} / \mathrm{h}$, syncline III/IV) and the Schwarzwasser valley $(143 \mathrm{~m} / \mathrm{h})$. On the limb of the synclines, velocities are lower $(56 \mathrm{~m} / \mathrm{h})$. Low velocities were also found in the $\mathrm{W}$ section of syncline $\mathrm{V} / \mathrm{VI}$, where the catchment is smaller and partially covered by sandstone and marl $(60 \mathrm{~m} / \mathrm{h})$. The flow velocity in the limestone bank within the Drusberg marl is ten times lower that in the main karst
Tab. 4. Linear flow velocities in the Hochifen-Gottesacker area quantified by tracer tests.

\begin{tabular}{|c|c|c|c|c|}
\hline $\begin{array}{l}\text { Flow } \\
\text { paths }\end{array}$ & Geology & \begin{tabular}{|l|} 
Hydrologic \\
conditions
\end{tabular} & $\begin{array}{c}\text { Flow } \\
\text { highest } \\
{[\mathrm{m} / \mathrm{h}]}\end{array}$ & $\begin{array}{l}\text { velocity } \\
\text { |dominant } \\
{[\mathrm{m} / \mathrm{h}]}\end{array}$ \\
\hline IP9-Au & \multirow[t]{2}{*}{ Trough of a large and open syncline } & low-high* & 149 & 141 \\
\hline IP2-Bü & & moderate & 331 & 233 \\
\hline IP11-Ka & Trough of a small syncline & low-high* & 64 & 60 \\
\hline IP13-SI & Limb of a syncline & low-high* & 56 & 56 \\
\hline IP7-Sb & \multirow{4}{*}{$\begin{array}{l}\text { Karst aquifer in the } \\
\text { Schwarzwasser valley }\end{array}$} & low-high* & 98 & 66 \\
\hline IP3-Au & & moderate & 160 & 143 \\
\hline IP6-Au & & \multirow[t]{2}{*}{ low } & 147 & 85 \\
\hline IP6-Sb & & & 100 & 71 \\
\hline IP14-Ls & Limestone bank in Drusberg marl marl & low-high* & 25 & 23 \\
\hline IP8-Ru & Rockfall mass & low-high* & 113 & 81 \\
\hline
\end{tabular}

aquifer but still indicates karstification $(23 \mathrm{~m} / \mathrm{h})$. High flow velocities were also observed in the rockfall mass $(81 \mathrm{~m} / \mathrm{h})$.

The tracer test between the estavelle and the karst springs in the lower section of the Schwarzwasser valley was carried out during stable low-flow conditions, and the spring discharge rates were measured using the salt-dilution method. It was thus possible to calculate the tracer recovery rate and to determine the mean transit times and dispersivities by analytical modelling. This was done with the computer programme Traci95 using a 1-D single-fissure-dispersion-model in the multi-peak modus (Maloszewski et al. 1994, Werner 1998). The data set of this tracer test can be simulated by overlying two theoretical curves. The first peak corresponds to the fast conduit network, while the second peak may indicate the presence of a slower flow system. The longitudinal dispersivities for the first peak range between $15.7 \mathrm{~m}$ and $24.5 \mathrm{~m}$, typical values for a karst system. The total recovery rate in the sampled springs is $91 \%$. The missing $9 \%$ probably reached the bottom spring. 


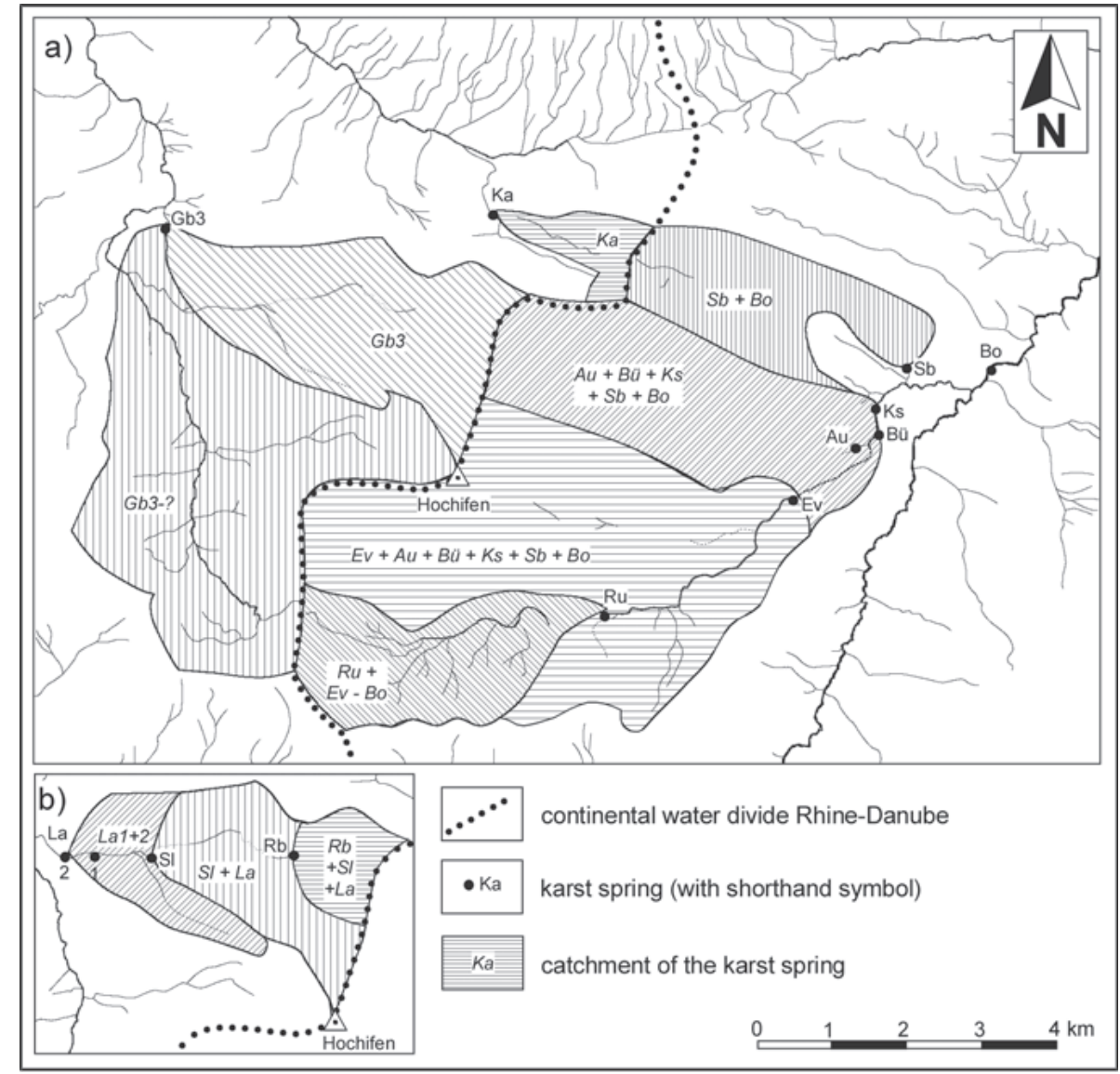

Fig. 16. a) Catchments of important springs in the Hochifen-Gottesacker area delineated by means of tracer tests and analysis of the fold structures; b) detail from the western Gottesacker. Flow measurements and hydrochemistry indicate that Gb3 receives inflow from the Subersach River, so that the entire valley upstream from this spring is part of the spring catchment (Gb3-? not directly confirmed by tracer tests).
The high flow velocities, concentrations and recovery rates of the tracers also demonstrate the high vulnerability of the karst groundwater to contamination. The breakthrough curves that were obtained during the experiment in September 1997 demonstrate that karst aquifers are vulnerable to contamination in a double way: Contaminants may rapidly arrive at the springs, and contamination may last for a long time on a relatively high level (Fig. 11).

\section{Acknowledgements}

The research presented in this paper was prepared at the Dept. of Applied Geology, Univ. Karlsruhe within the framework of my diploma and PhD thesis. I am grateful to Prof. Dr. H. Hötzl (thesis director). I thank C. Tomsu, M. Sinreich and J. Huth who contributed with their diploma works, and all students, colleagues and friends who helped me with the sampling. I am grateful to T. Fritz and his family and K. Keßler for permanent friendly support. I thank E. Medley and Prof. Dr. C. Groves for corrections, and the reviewers for helpful comments. The Landeswasserbauamt Bregenz and the Raiffeisen Stiftung Kleinwalsertal funded parts of this work.

\section{REFERENCES}

AUdRA, P. 1994: Karsts alpins. Genèse de grands réseaux souterrains: Exemples le Tennengebirge (Autriche), l'Ile de Crémieux, la Chartreuse et le Vercors (France). Karstologia Mémoires, 5, 280 p.
BAUER, F. 1989: Die unterirdischen Abflußverhältnisse im Dachsteingebiet und ihre Bedeutung für den Karstwasserschutz. Report, UBA-89-028, 73 p.

BögLI, A. 1978: Karsthydrographie und physische Speläologie. Springer, Berlin, $292 \mathrm{p}$.

Bögli, A. \& Harum, T. (eds.) 1981: Hydrogeologische Untersuchungen im Karst des hinteren Muotatales (Schweiz). Steir. Beitr. Hydrogeol. 33, $125-264$.

Bollinger, D. 1988: Die Entwicklung des distalen Osthelvetischen Schelfs im Barremian und Früh-Aptian (Drusberg-, Mittagsspitz- und SchrattenkalkFm.). Mitt. geol. Inst. ETH u. Univ. Zürich 259a, 136 p.

Cornaton, F. \& Perrochet, P. 2002: Analytical 1D dual-porosity equivalent solutions to 3D discrete single-continuum models. Application to karstic spring hydrograph modelling. Journal of Hydrology 262, 165-176.

Cramer, K. 1959: Die Geologie des Mahdtales und der Karst des Gottesackergebietes. Master thesis, TH Munich, $80 \mathrm{p}$.

Drew, D. \& HöTZL, H. (eds.) 1999: Karst Hydrogeology and Human Activities. Impacts, Consequences and Implications. - International Contributions to hydrogeology (IAH) 20, $322 \mathrm{p}$.

ECKert, M. 1902: Das Gottesackerplateau, ein Karrenfeld im Allgäu. Studien zur Lösung des Karrenproblems. - Wissenschaftl. Ergänzungshefte zur Zeitschr. d. D. u. Ö. Alpenvereins 1,1-108.

EisBacher, G.H. 1996: Einführung in die Tektonik, 2. Auflage. Enke, Stuttgart, $374 \mathrm{p}$.

FöLLMI, K.B. 1986: Die Garschella- und Seewer Kalk-Formation (Aptian-Santonian) im Vorarlberger Helvetikum und Ultrahelvetikum. Mitt. geol. Inst. ETH u. Univ. Zürich 262, 391 p.

FölLmi, K.B. \& OuweHAND, P.J. 1987: Garschella-Formation und GötzisSchichten (Aptian-Coniacian): Neue stratigraphische Daten aus dem Helvetikum der Ostschweiz und des Vorarlbergs. Eclogae geol. Helv. 80 141-191. 
ForD, D. \& Williams, D.W. 1989: Karst Geomorphology and Hydrology. Unwin Hyman, Boston, 601 p.

Fumy, R., Mammel, F., Niggemann, S., Orth, J.-P., Rosendahl, W., Schafroth, J., Vater, K. \& Wolf, A. 2000: Die Höhlen des Gottesacker-Hochifen-Gebietes. In: Hochifen und Gottesacker, eine Karstlandschaft zwischen Bregenzer Wald und Allgäuer Alpen. Karst und Höhle 2000/2001, 89-157.

GoldSCHEIDER, N. 1997: Hydrogeologische Untersuchungen im alpinen Karstgebiet Gottesacker und Schwarzwassertal (Allgäu/Vorarlberg). Master thesis, Univ. Karlsruhe, 128 p.

Goldscheider, N. 2000: Von der Zerstörung einer Höhle und den Folgen fürs Karstwasser. In: Hochifen und Gottesacker, eine Karstlandschaft zwischen Bregenzer Wald und Allgäuer Alpen. Karst und Höhle 2000/2001, 51-82.

GOLDSCHEIDER, N. \& HÖTZL, H. 1999: Hydrogeological characteristics of folded alpine karst systems exemplified by the Gottesacker Plateau (GermanAustrian Alps). Acta Carsologica 28, 87-103.

Goldscheider, N., HötZl, H. \& Käss, W. 2001: Comparative Tracer Test in the Alpine Karst System Hochifen-Gottesacker, German-Austrian Alps. Beitr. z. Hydrogeologie 52, 145-158.

Goldscheider, N., Niggemann, S. \& Rosendahl, W. 2000: Überlegungen zur Speläogenese im Gebiet von Hochifen und Gottesacker. In: Hochifen und Gottesacker, eine Karstlandschaft zwischen Bregenzer Wald und Allgäuer Alpen. Karst und Höhle 2000/2001, 159-164.

Goldscheider, N., Orth, J.-P., Vater, K. \& Hötzl, H. 1999: Die Schwarzwasserhöhle, eine hydrogeologisch bedeutsame Estavelle im alpinen Karstgebiet Hochifen-Gottesacker. Laichinger Höhlenfreund 34, 69-96.

GolDSCHEIDER, N. 2002: Hydrogeology and vulnerability of karst systems, examples from the Northern Alps and Swabian Alb. PhD thesis (Dissertation), Schr. Angew. Geol. Karlsruhe 68, 236 p.

GÖPPERT, N., GOLDSCHEIDER, N. \& SCHOlZ, H. 2002: Karsterscheinungen und Hydrogeologie karbonatischer Konglomerate der Faltenmolasse im Gebiet Hochgrat und Lecknertal (Bayern/Vorarlberg). Beitr. z. Hydrogeologie 53, 21-44.

Häuselmann, P., Jeannin, P.Y. \& Bitterli, T. 1999: Relationships between karst and tectonics: case-study of the cave system north of Lake Thun (Bern, Switzerland). Geodinamica Acta 12, 377-387.

Häuselmann, P., Otz, M. \& Jeannin, P.Y. 2003: A review of the dye tracing experiments done in the Siebenhengste karst region (Bern, Switzerland). Eclogae geol. Helv. 96, 23-36.

Herold, T., Jordan, P. \& ZWAHLEN, F. 2000: The influence of tectonic structures on karst flow patterns in karstified limestones and aquitards in the Jura Mountains, Switzerland. Eclogae Geologicae Helvetiae, 93, 349-362.

HöтzL, H. 1998: Karst Groundwater. In: Käss, W. (1998) Tracing Technique in Geohydrology, 398-426.

HutH, J. 1998: Geologisch-tektonische Kartierung und hydrochemische Untersuchungen im nordwestlichen Gottesackergebiet (Vorarlberg/Bayern). Master thesis, Univ. Karlsruhe, 105 p.

JEANNIN, P.Y., 2001. Modeling flow in phreatic and epiphreatic karst conduits in the Hölloch cave (Muotatal, Switzerland). Water Resources Research 37, 191-200.

Käss, W. 1998: Tracing Technique in Geohydrology. Balkema, Rotterdam, $581 \mathrm{p}$.

Maloszewski, P. 1994: Mathematical modelling of tracer experiments in fissured rocks with porous matrix. J. Hydrol. 79: 333-358.

MAURIN, V. \& ZÖTL, J. 1959: Die Untersuchung der Zusammenhänge unterirdischer Wässer mit besonderer Berücksichtigung der Karstverhältnisse: Großversuche im nordostalpinen Karst (Hochschneeberg, Niederösterreich). Steir. Beitr. z. Hydrogeol. 1, 50-55.
Oberhauser, R. 1951: Zur Geologie des Gebietes zwischen Canisfluh und Hohem Ifen (Bregenzerwald). Ph.D. thesis Univ. Innsbruck, 45 p.

RIEG, A. 1994: Zur Hydrologie im Karstgebiet Churfirsten-Alvier. PhD thesis, Institute of Hydrology, Univ. Freiburg, 213 p.

Rosendahl, W. 2000: Die Formen des Oberflächenkarstes (Exokarst) im Gebiet Hochifen-Gottesackerplateau (Kleinwalsertal). In: Hochifen und Gottesacker, eine Karstlandschaft zwischen Bregenzer Wald und Allgäuer Alpen. Karst und Höhle 2000/2001, 83-88.

Schmidt-Thomé, P. 1960: Zur Geologie und Morphologie des Ifengebirgsstockes (Allgäu). Erdkunde 14, 181-195.

Scholz, H. 1995: Bau und Werden der Allgäuer Landschaft. Schweizerbart, Stuttgart, $305 \mathrm{p}$.

SCHWERD, K. 1996: Erläuterungen zur Geologischen Karte von Bayern 1:500.000. Bayer. Geol. Landesamt, 329 p.

SinREICH, M. 1998: Hydrogeologische Untersuchungen im oberen Schwarzwassertal (Vorarlberg). Wechselwirkungen zwischen Bergsturzmasse, Karstgrundwasserleiter und Flyschgebiet. Master thesis Univ. Karlsruhe, 118 p.

SinReich, S., GoldSCheider, N. \& HötZl, H. 2002: Hydrogeologie einer alpinen Bergsturzmasse (Schwarzwassertal, Vorarlberg). Beitr. z. Hydrogeologie 53, 5-20.

SPÖCKER, R.G. 1961: Das Hölloch als geographisches Element. In: SCHMIDTTноме́, P. (ed.): Das Hölloch bei Riezlern im Kleinen Walsertal (AllgäuVorarlberg), eine karstkundliche Monographie. Wiss. Alpenvereinsh. 18, 33-53.

Tomsu, C. 1998: Zur Hydrogeologie des Karstes zwischen Hochifen und Subersach, Hinterer Bregenzerwald, Vorarlberg. Master thesis Univ. Karlsruhe, 90 p.

ToussainT, B. 1971: Hydrogeologie und Karstgenese des Tennengebirges (Salzburger Kalkalpen). Steir. Beitr. z. Hydrogeologie 23, 5-115.

Trimmel, H. (ed.) 1998: Die Karstlandschaften der österreichischen Alpen und der Schutz ihres Lebensraumes und ihrer natürlichen Ressourcen. Fachausschuß Karst, CIPRA Österreich, 119 p.

WAGNeR, G. 1950: Rund um Hochifen und Gottesackergebiet. Eine Einführung in die Erd- und Landschaftsgeschichte des Gebietes zwischen Iller und Bregenzer Ach. Rau, Öhringen, 116 p.

Werner, A. 1998: Hydraulische Charakterisierung von Karstsystemen mit künstlichen Tracern. Ph.D. thesis Univ. Karlsruhe, Schr. Angew. Geol. Karlsruhe 51,169 p.

WiLdberger, A. 1996: Zur Geologie und Hydrogeologie des Karstes der Sulzfluhhöhlen (St. Antönien, Graubünden). Stalactite 46, 112-118

WYSSLING, G. 1986: Der frühkretazische Schelf in Vorarlberg und im Allgäu, Stratigraphie, Sedimentologie und Paläogeographie. Jb. Geol. B.-Anst. 129, 161-265.

ZACHER, W. 1973: Das Helvetikum zwischen Rhein und Iller (Allgäu-Vorarlberg). Tektonische, paläogeographische und sedimentologische Untersuchungen. Geotekt. Forsch. 44, 1-74.

ZACHER, W. 1985: Geologische Karte von Bayern 1:100 000, Blatt 670 Oberstdorf. Bayer. Geol. Landesamt, Munich.

ZöTL, J. 1961: Die Hydrographie des nordalpinen Karstes. Steir. Beitr. Hydrogeol., 1960/61, 163p.

ZWAHLEN, F. (ed.) 2004: Vulnerability and risk mapping for the protection of carbonate (karst) aquifers, final report COST Action 620. EUR 20912, European Commission, Brussels, 297 p.

Manuscript received July 8, 2004

Revision accepted February 3, 2005 
